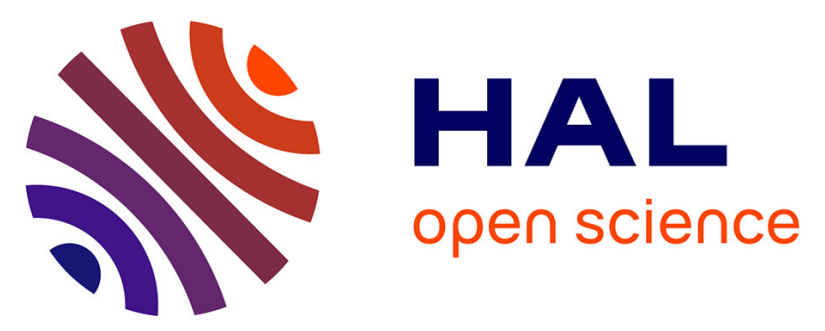

\title{
Synthesis and Characterization of Epoxy Thermosetting Polymers from Glycidylated Organosolv Lignin and Bisphenol A
}

Lena Charlotte Over, Etienne Grau, Stéphane Grelier, Michael A. R. Meier, Henri Cramail

\section{To cite this version:}

Lena Charlotte Over, Etienne Grau, Stéphane Grelier, Michael A. R. Meier, Henri Cramail. Synthesis and Characterization of Epoxy Thermosetting Polymers from Glycidylated Organosolv Lignin and Bisphenol A. Macromolecular Chemistry and Physics, 2017, 218 (8), 10.1002/macp.201600411 . hal01611278

\author{
HAL Id: hal-01611278 \\ https://hal.science/hal-01611278
}

Submitted on 17 Nov 2019

HAL is a multi-disciplinary open access archive for the deposit and dissemination of scientific research documents, whether they are published or not. The documents may come from teaching and research institutions in France or abroad, or from public or private research centers.
L'archive ouverte pluridisciplinaire HAL, est destinée au dépôt et à la diffusion de documents scientifiques de niveau recherche, publiés ou non, émanant des établissements d'enseignement et de recherche français ou étrangers, des laboratoires publics ou privés. 
DOI: 10.1002/marc.((insert number)) ((or ppap., mabi., macp., mame., mren., mats.))

\section{Full Paper}

\section{Synthesis and characterization of epoxy resins from glycidylated organosolv lignin and bisphenol $\mathrm{A}^{\mathrm{a}}$}

Lena Charlotte Over, Etienne Grau, Stéphane Grelier, Michael A. R. Meier,* Henri Cramail*

L. C. Over, Prof. M. A. R. Meier

Karlsruhe Institute of Technology (KIT), Institute of Organic Chemistry (IOC), Laboratory of Applied Chemistry, Straße am Forum 7, Building 30.48, D-76131 Karlsruhe, Germany. E-mail: m.a.r.meier@kit.edu

L. C. Over, Dr. E. Grau, Prof. S. Grelier, Prof. H. Cramail

Univ. Bordeaux, Laboratoire de Chimie des Polymères Organiques, UMR 5629, F-33607

Pessac Cedex, France. E-mail: cramail@enscbp.fr

Centre National de la Recherche Scientifique, Laboratoire de Chimie des Polymères Organiques, UMR 5629, F-33607 Pessac Cedex, France

\footnotetext{
${ }^{\text {a }}$ Supporting Information is available online from the Wiley Online Library or from the author.
} 
Abstract. Diglycidylether of bisphenol A (BPA) and isophorone diamine (IPDA) are industrially used for epoxy resin synthesis. Herein, glycidylated Organosolv lignin (GOL) is cured with DGEBA and IPDA for intensive studies. Organosolv lignin (OL) is therefore first glycidylated with epichlorohydrin to a material with an epoxy content of $3.2 \mathrm{mmol} / \mathrm{g}$ and analyzed via FTIR, ${ }^{1} \mathrm{H}$ and ${ }^{31} \mathrm{P}$ NMR. Epoxy resins with up to $42 \mathrm{wt} \%$ GOL are cured in DSC crucibles, analyzing the residual reaction heat. Characterization of dog bone shaped specimens is described with regard to structural properties from scanning electron microscopy (SEM) and FT-IR, thermal properties by differential scanning calorimetry (DSC) and thermogravimetric analysis (TGA), as well as mechanical properties by dynamic mechanical analysis (DMA) and stress/strain measurements. A lignin content between 8 and $33 \%$ leads to higher cross-linking density, resulting in a higher glass transition, lower swelling percentage and increased stiffness (Young's modulus) if compared to non-GOL resins.

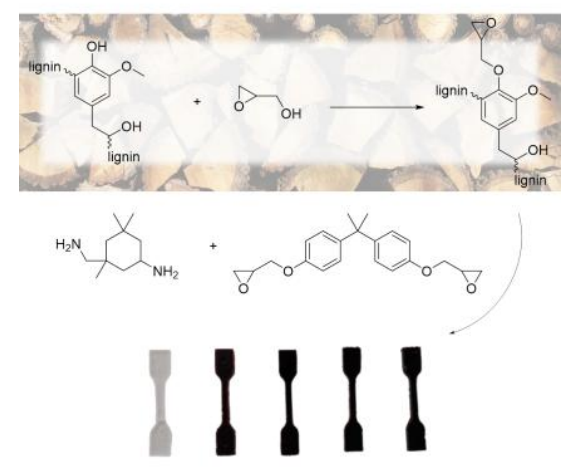




\section{Introduction}

Bisphenol-A (BPA) is one of the most produced chemicals worldwide and broadly used as monomer for polycarbonates, epoxy resins, polyesters or other polymers. ${ }^{[1]}$ It finds applications in consumer products including food containers, bottles, tableware and paper for food packaging and medical equipment. ${ }^{[2]}$ However, BPA exposure to the environment and to humans is followed by health concerns. ${ }^{[2-5]}$ Although its activity as xenoestrogen is already known for decades, ${ }^{[6]}$ the production volume in 2012 was 4.6 million tons, with a rising trend. $^{[7]}$ In addition to health care issues, BPA is obtained from fossil resources. The decreasing fossil feedstock is a growing problem demanding new synthetic routes from renewable resources. As one of the most abundant biopolymers on earth, lignin is a highly available renewable resource. ${ }^{[8]}$ Due to its high aromatic content, it is investigated either for the replacement of aromatic monomers, obtained from lignin degradation (e.g., vanillin, eugenol, other 4-substituted or 2-methoxy phenols ${ }^{[9-11]}$ ), or used as macromolecular structure for polymeric materials (i.e. in blends or composites). The monomer approach towards renewable based epoxy resins from lignin-obtained phenols was already intensively investigated. Vanillin-based epoxy resins were described in detail by Caillol et al. ${ }^{[12-14]}$ Recently, epoxy thermosets from glycidylated iso-eugenol were presented. ${ }^{[15]}$ In contrast, the macromolecular approach, i.e. the use of modified lignin as reactive monomer in epoxy resins, is more challenging due to the heterogenic structure of lignin and structural differences emerging through pulping procedures (Kraft, Organosolv, sulfite, pyrolysis, steam explosion,...).

The direct use of lignin as macromolecular structure in epoxy resins was limited for a long time to the use in blends and as ring-opening reagents. ${ }^{[16-22]}$ In some cases, modification of lignin becomes necessary. For instance, hydroxy groups in lignin were converted to acidic 
groups via esterification with succinic anhydride, increasing the reactivity towards epoxides. ${ }^{[23]}$ In the last years, the interest for using lignin as epoxide compound increased and various approaches of using glycidylated lignin in epoxy resins were presented. Malutan et al. showed that the glycidylation of Kraft lignin depends on the origin of lignin and on different temperatures and reaction times. ${ }^{[24]}$ For instance, wheat straw lignin lead to higher epoxy values than grass straw lignin under the same reaction conditions. Synthesis of cured epoxy resins with lignin are described with a) a conventional coating primer, ${ }^{[25]}$ b) the diglycidylether of BPA (DGEBA) as additional epoxide compound and different hardeners (triethylenetatraamine ${ }^{[26]} 4,4^{\prime}$-diaminodiphenylmethane $(\mathrm{DDM})^{[27,28]}$ or a imidazole-based hardener ${ }^{[29]}$ ) or c) without a second epoxide compound, using a tung oil derived hardener ${ }^{[30]}$ or a conventional novolac. ${ }^{[31]}$ The various publications address different aspects of the characteristics of lignin-based resins. Some focus on thermal properties ${ }^{[27,31]}$ and others analyze specific applications, such as epoxy asphalts ${ }^{[30]}$ or coatings. ${ }^{[25]}$ Recent publications $^{2}$ examined the DSC curing behavior of lignin-based epoxy resins, analyzing the activation energy. ${ }^{[28,30]}$

In this work, the influence of macromolecular GOL content in a conventional epoxy resin with DGEBA was examined in detail. Isophorone diamine (IPDA) was chosen as cross-linker, since it is a common industrial amine hardener. A full analysis of basic properties is covered by analysis of curing behavior via DSC, structural information from IR and SEM, thermal properties from DSC and TGA, mechanical properties obtained by strain/stress measurement and DMA, as well as swelling in THF.

\section{Experimental Section}

\subsection{Materials}

The following chemicals were obtained from commercial sources and used without further purification: 
Biphenol-A diglycidyl ether (sigma-aldrich), dichloromethane (sigma-aldrich), diphosphorous pentoxide (VWR), epichlorohydrin (sigma-aldrich), hydrochloric acid (37\%, fisher scientific) isophorone diamine (TCI), magnesium sulfate (VWR), n-hexane (sigma-aldrich), sodium chloride (fisher scientific), potassium hydroxide (sigma-aldrich), pyridine (acros), tetrabutyl ammonium bromide (Acros), tetrahydrofuran (sigma-aldrich).

\subsection{Reaction procedures}

\subsubsection{Organosolv Pulping}

The Organosolv pulping was performed at the Thünen Institute of Wood Research (Hamburg, Germany). European beech wood (F. sylvatica L.) chips $(10.8 \mathrm{~kg})$ were treated with ethanol/water $(50 \mathrm{v} \%)$ at $170{ }^{\circ} \mathrm{C}$ for $90 \mathrm{~min}$ with a catalytic amount $\mathrm{H}_{2} \mathrm{SO}_{4}(0.5 \mathrm{wt} \%$ based on dry wood). The solid to liquid ratio was 1:4. The lignin fraction in solution was separated from the solid fraction by filtration. Organosolv lignin (OL) was precipitated in water at a $\mathrm{pH}$ value of around 2. The suspension was centrifuged and OL separated. OL was dried at $40{ }^{\circ} \mathrm{C}$ in a vacuum drying oven and isolated as a brown solid (785 g, $7.8 \mathrm{wt} \%)$. The total hydroxy content of this unmodified lignin was calculated to be $4.53 \mathrm{mmol} / \mathrm{g}$ (from ${ }^{31} \mathrm{P}$ NMR analysis).

\subsubsection{Glycidylation procedure}

Organosolv lignin $(25.0 \mathrm{~g}, 152 \mathrm{mmol} \mathrm{OH})$ was suspended in epichlorohydrin $(100 \mathrm{~mL}, 1.28$ mol). Under ice cooling, tetrabutylammonium bromide, TBABr, (9.5 g, $29.6 \mathrm{mmol})$ was slowly added and the mixture stirred for $30 \mathrm{~min}$. Portion-wise, potassium hydroxide (29.9 g, $534 \mathrm{mmol}$ ) was added over 2.5 hours. After stirring for another 5 hours at room temperature, the mixture was diluted with dichloromethane $(300 \mathrm{~mL})$ and extracted with water $(3 \times 200$ $\mathrm{mL})$. The aqueous phase was extracted with dichloromethane $(2 \times 50 \mathrm{~mL})$ and the combined organic layers were washed with saturated sodium chloride solution (100 mL). After separation, the organic layer was dried over magnesium sulfate, filtrated and concentrated in a 
rotary evaporator to $200 \mathrm{~mL}$. The product was precipitated in $\mathrm{n}$-hexane, filtrated and dried at $10^{-3}$ mbar over diphosphorous pentoxide.

${ }^{1} \mathrm{H}$ NMR (300 MHz, DMSO-d,$\delta$ ): 6.87 - 6.61 (m, Ar H), 4.09 - 3.35 (m, - $\mathrm{OCH}_{3}$, epoxyCH), 2.86 - 2.55 (m, aliphatic H); IR (ATR): v = 3450 (br), 2994 (w), 2943 (w), 2873 (w), 1725 (w), 1597 (m), 1502 (m), 1457 (m), 1413 (m), 1330 (m), 1228 (m), 1125 (s), 1030 (m), $909(\mathrm{~m}), 845(\mathrm{~m}), 758(\mathrm{w}) \mathrm{cm}^{-1}$.

\subsubsection{Preparation of epoxy resin}

Glycidylated lignin and bisphenol-A diglycidyl ether were mixed in different ratios to a total amount of $1.50 \mathrm{~g}$. Isophorone diamine was added in the ratio $n_{\text {epoxide }}: n_{\text {amine }}=2: 1$, giving a molar ratio of 1 , as one amine can react with two epoxides. The materials were mixed homogeneously, poured into dog bone shaped molds and cured in the oven for 1 hour at 70 ${ }^{\circ} \mathrm{C}$, then heated to $120{ }^{\circ} \mathrm{C}$ for 2 more hours.

\subsection{Analytical procedures}

\subsubsection{Epoxy content titration}

An exact amount $\left(\mathrm{m}_{\mathrm{S}}\right)$ of approximately $200 \mathrm{mg}$ glycidylated lignin was solved in $25.0 \mathrm{~mL}$ pyridine $/ \mathrm{HCl}$ solution (Stock solution: $500 \mathrm{~mL}$ pyridine and $8.30 \mathrm{~mL}$ concentrated hydrochloric acid (37\%)) and refluxed for $20 \mathrm{~min}$ at $115^{\circ} \mathrm{C}$. The sample solution was titrated with $2 \mathrm{M} \mathrm{NaOH}$ solution to neutral $\mathrm{pH}$ with a required volume $V_{\mathrm{s}}$. A blank was measured

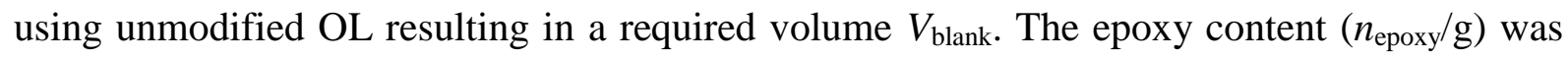
calculated as followed:

$n_{\text {epoxy }} / g=\frac{\left(V_{\text {blank }}-V_{S}\right) * 2 \mathrm{~mol} / \mathrm{L}}{m_{S}}$ 


\subsection{2 ${ }^{1} \mathrm{H}$ NMR Spectroscopy}

${ }^{1} \mathrm{H}$ NMR spectra were measured in DMSO- $d_{6}$ with a Bruker AC 300 using 256 scans and a time delay $d l$ of 10 seconds at $25{ }^{\circ} \mathrm{C}$. The sample concentration was $20 \mathrm{mg} / \mathrm{mL}$. All ${ }^{1} \mathrm{H}$ NMR data are reported in ppm relative to the solvent signal for DMSO- $d_{6}$ at $2.50 \mathrm{ppm}$.

\subsection{3 ${ }^{31}$ P NMR Spectroscopy}

An exact amount of $28-32 \mathrm{mg}$ of the lignin sample was diluted in $400 \mu \mathrm{L} \mathrm{CDCl}_{3} /$ pyridine (1 : 1.6). $150 \mu \mathrm{L}$ of a solution of chromium(III) acetylacetonate $(3.6 \mathrm{mg} / \mathrm{mL})$ as relaxation agent and cyclohexanol $(4.0 \mathrm{mg} / \mathrm{mL})$ as internal standard in $\mathrm{CDCl}_{3} /$ pyridine $(1: 1.6)$ were added and the solution was stirred for 5 minutes. 2-Chloro-4,4,5,5-tetramethyl-1,2,3dioxaphospholane $(70 \mu \mathrm{L})$ was added and the solution was transferred into a NMR tube for subsequent measurement in a Bruker Ascend ${ }^{\mathrm{TM}} 400 \mathrm{MHz}$ spectrometer with 512 scans, a delay time d1 of 5 seconds and a spectral width of $75 \mathrm{ppm}(102-177 \mathrm{ppm})$. The chemical shifts are reported relative to the reaction product of 2-chloro-4,4,5,5-tetramethyl-1,2,3dioxaphospholane with water at $132.2 \mathrm{ppm}$. Integrals are assigned to the functional groups as followed: $\delta=150.0$ - 145.5 (aliphatic hydroxy groups), 145.5 - 144.7 (cyclohexanol), $144.7-$ 136.6 (phenolic hydroxy groups), $136.6-133.6$ (carboxylic acids) ppm. ${ }^{[32]}$ In the region of the phenolic hydroxy groups, syringyl $(144.7-141.0 \mathrm{ppm})$ and guiacyl units $(141.0-136.6$ ppm) can be distinguished

\subsubsection{Differential Scanning Calorimetry (DSC)}

Differential Scanning Calorimetry (DSC) was performed on a DSC Q100 system from TA instruments. For reaction heat studies, $6-8 \mathrm{mg}$ of the reaction mixture was heated in aluminum crucibles from $0{ }^{\circ} \mathrm{C}$ to $250^{\circ} \mathrm{C}$ with a heating rate of $10 \mathrm{~K} \mathrm{~min}^{-1}$.

The cured resin were analyzed with the following heating program with two cycles: first heating cycle: $-50{ }^{\circ} \mathrm{C}-200{ }^{\circ} \mathrm{C}\left(10 \mathrm{~K} \mathrm{~min}^{-1}\right)$; Cooling: $200--50{ }^{\circ} \mathrm{C}\left(-20 \mathrm{~K} \mathrm{~min}^{-1}\right)$, second heating cycle: $-50^{\circ} \mathrm{C}-250{ }^{\circ} \mathrm{C}\left(10 \mathrm{~K} \mathrm{~min}^{-1}\right)$. The glass transition temperature $\left(T_{\mathrm{g}}\right)$ was defined 
as the midpoint of the change in heat capacity occurring over the transition in the second heating cycle.

\subsubsection{FT-IR Spectroscopy}

Infrared spectra were recorded on a Bruker alpha-p instrument applying ATR technology.

\subsubsection{Scanning electron microscopy (SEM)}

SEM was performed on a HITACHI-S570 with an accelerating voltage of $12 \mathrm{kV}$. The surface was coated with gold by sputtering for $14 \mathrm{~s}$ prior to the measurements using a Balzers UNION SCD 040. Digital Image Scanning System and Processing System (DISS and DIPS) from point electronic were used to generate the images.

\subsubsection{Thermogravimetric analysis (TGA)}

Thermogravimetric analyses (TGA) were performed on a TGA-Q500 system from TA instruments at a heating rate of $5 \mathrm{~K} \mathrm{~min}^{-1}$ under synthetic air flow employing a sample mass of approximately $15 \mathrm{mg}$. From the two degradation temperatures of 5\% $\left(T_{\mathrm{d} 5 \%}\right)$ and $30 \%\left(T_{\mathrm{d}}\right.$ $30 \%)$ weight loss, the statistic heat-resistant index $\left(T_{\mathrm{s}}\right)$ is calculated as follows: ${ }^{[33]}$

$T_{s}=0.49 \cdot\left(T_{d 5 \%}+0.6 \cdot\left(T_{d 30 \%}-T_{d 5 \%}\right)\right)$

\subsubsection{Dynamic Mechanical Analysis (DMA)}

A DMA RSA 3 system from TA instruments was used to modulate from $25{ }^{\circ} \mathrm{C}$ to $240{ }^{\circ} \mathrm{C}$ at a heating rate of $5 \mathrm{~K} \mathrm{~min}^{-1}$. The measurements were performed in 3-point bending mode at a frequency of $1 \mathrm{~Hz}$, an initial force of $0.5 \mathrm{~N}$ and a strain sweep of $0.01 \%$. The storage modulus $E^{\prime}$ is defined as the constant value below and over the glass transition. The glass transition temperature $\left(T_{\mathrm{g}}\right)$ is defined as the onset of the change in the storage modulus. The crosslinking density can be calculated from the following equation according to rubber elastic theory: ${ }^{[34]}$

$$
v=\frac{E^{\prime}}{\phi \cdot R \cdot\left(T_{\alpha}+30 K\right)}
$$


where $\mathrm{E}^{\prime}$ is the storage modulus of the cured resin in the rubbery state, $\phi$ is the front factor (approximately 1 in Flory theory ${ }^{[35]}$ ), $R=8.314 \mathrm{~J} \mathrm{~mol}^{-1} \mathrm{~K}^{-1}$ the gas constant and $T_{\alpha}$ is the maximum of tan delta (tan delta $=E$ ''/E', with E', defined as loss modulus).

\subsubsection{Stress/strain measurement}

Stress/strain measurements were performed on a MTS Elite 25 system using a elongation at break method with dog bone shaped specimens (width $=2 \mathrm{~mm}$; thickness $=2 \mathrm{~mm}$ and length of fixed section $=17.5 \mathrm{~mm}$ ) using a $500 \mathrm{~N}$ load cell and a crosshead speed of $1 \mathrm{~mm} \mathrm{~min}{ }^{-1}$. Young's modulus $(E)$ was determined from the linear part of the stress/strain curves for all samples.

\subsubsection{Swelling properties}

Swelling properties of weighted bar samples $\left(m_{0}\right)$ of the cured resins were analyzed. After immersion in THF for 24 hours, the swollen samples were dried between paper and weighted again $\left(m_{\mathrm{SW}}\right)$. The samples were dried at $60{ }^{\circ} \mathrm{C}$ for 24 hours and weighted $\left(m_{\mathrm{D}}\right)$ to obtain the swelling percentage

Swelling $(\%)=\frac{m_{S W}-m_{D}}{m_{D}} * 10$

and the soluble part of the networks

Soluble part $(\%)=\left(1-\frac{m_{D}}{m_{0}}\right) * 100$

\section{Results and Discussion}

\subsection{Characterization of the glycidylated Organosolv lignin}

OL was isolated at Thünen Institute of Wood Research via an ethanol—water pulping and used without further fractioning (for details, see experimental part). A full characterization of this batch OL can be found in the literature. ${ }^{[36]}$ Glycidylation of OL with epichlorohydrin in the presence of $\mathrm{NaOH}$ and $\mathrm{TBABr}$ was performed without external heating. The exothermic 
reaction led to heat evolution, so that ice cooling was necessary in the first hours to avoid temperatures above $50{ }^{\circ} \mathrm{C}$. In literature, the increase of reaction temperatures from 50 to 70 or $90{ }^{\circ} \mathrm{C}$ led to lower epoxy contents. ${ }^{[24,37]}$ However, no reaction conditions at room temperature are described. In the present work, a lignin epoxy material with an epoxy content of 3.2 $\mathrm{mmol} / \mathrm{g}$ was obtained. The value is in the range of similarly functionalized steam exploded $\operatorname{lignin}^{[29,31]}$ or Organosolv lignin ${ }^{[27]}$ and higher than for glycidylated Kraft or acetic acid lignin. ${ }^{[24,26,37]}$ The comparison reveals that Organosolv and steam exploded lignin result in higher epoxy contents. A reason for this behavior may be the better solubility and lower molar mass of these lignins. Moreover, a higher aromatic hydroxyl group content in these lignins is present due to the pulping conditions. In addition to the titration result, ${ }^{31} \mathrm{P}$ NMR was performed. The glycidylated compound showed a decrease of the aromatic hydroxy groups from $1.83 \mathrm{mmol} / \mathrm{g}$ to $0 \mathrm{mmol} / \mathrm{g}$, indicating that all phenolic groups reacted (Table 1 ). The value for the aliphatic hydroxy groups decreased from 2.70 to $1.92 \mathrm{mmol} / \mathrm{g}$ leading to an overall functionalization of at least $2.6 \mathrm{mmol} / \mathrm{g}$. The value is lower than the one obtained from titration, which may indicate that epoxy rings were partially opened. A ring opening with water as nucleophile would result in two new aliphatic hydroxy groups, explaining a small increase of aliphatic hydroxy groups and the change in signal shape of the aliphatic region (for ${ }^{31} \mathrm{P}$ spectra, see $\mathrm{SI}$ ).

Table 1. Characteristics of unmodified and glycidylated lignin.

\begin{tabular}{|c|c|c|c|c|}
\hline Quantity & $\begin{array}{l}\text { Epoxy } \\
\text { content }^{\text {a) }} \\
{[\mathrm{mmol} / \mathrm{g}]}\end{array}$ & $\begin{array}{l}\text { Aliphatic } \mathrm{OH} \\
\text { content }^{\text {b) }} \\
{[\mathrm{mmol} / \mathrm{g}]}\end{array}$ & $\begin{array}{l}\text { Aromatic } \mathrm{OH} \\
\text { content }^{\text {b) }} \\
{[\mathrm{mmol} / \mathrm{g}]}\end{array}$ & $\begin{array}{l}\text { Total OH } \\
\text { content }^{\text {b) }} \\
{[\mathrm{mmol} / \mathrm{g}]}\end{array}$ \\
\hline unmodified OL & 0 & 2.70 & 1.83 & 4.53 \\
\hline glycidylated OL & 3.2 & 1.92 & 0 & 1.92 \\
\hline
\end{tabular}

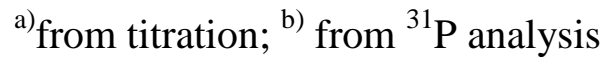


FT-IR analysis of glycidylated lignin revealed a significant decrease of hydroxy group stretching vibrations at $\sim 3450 \mathrm{~cm}^{-1}$ (Figure 1), indicating their functionalization. In addition, a new signal appeared at $909 \mathrm{~cm}^{-1}$, which is typical for the asymmetric stretching vibration band of C-O-C in epoxy functions. ${ }^{[38]}$ Vibrations of ether linkages, such as the newly formed C-Oglycidyl, show typical bands in the region between 1000 and $1200 \mathrm{~cm}^{-1}$. Here, a significant increase was observed. The signals of the functional groups that did not take place in the modification procedure, such as $\mathrm{C}-\mathrm{H}$ bonds $\left(2600-3000 \mathrm{~cm}^{-1}\right)$ and aromatic $\mathrm{C}=\mathrm{C}$ bonds (1502 and $1597 \mathrm{~cm}^{-1}$ ), did not change. The results are in agreement with previous reported FT-IR spectra for glycidylated lignins. ${ }^{[24,26,29-31,37]}$

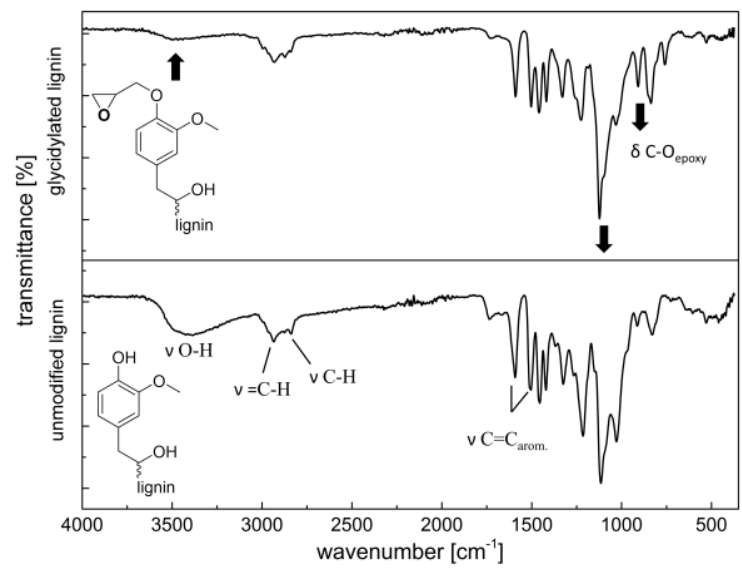

Figure 1. FT-IR spectra (ATR) of modified, glycidylated lignin (top) and unmodified lignin (bottom).

Analyzing the degradation temperature for $5 \%$ weight loss $\left(T_{\mathrm{d}} 5 \%\right)$, the thermal stability revealed an increase accompanied with glycidylation, from 233 to $269{ }^{\circ} \mathrm{C}$ (for TGA traces, see SI). The main difference occurred during the first $30 \%$ weight loss. At the $T_{\mathrm{d} 30 \%}$ value, the degradation traces assimilated. Both traces showed two main degradation steps. This first degradation process between 280 and $350{ }^{\circ} \mathrm{C}$ can be assigned to inter-unit ether bond cleavage in lignin. This results in evaporation of volatile aromatic compounds. ${ }^{[39,40]}$ A second step occurs between 500 and $600{ }^{\circ} \mathrm{C}$. At this temperature, aromatic rings are expected to decompose. ${ }^{[41]}$ This two-step degradation is characteristic for cross-linked materials with 
aromatic and ether functional groups as in lignin. This first degradation step is more relevant for glycidylated lignin compared to unmodified lignin as there are additional ether functions in the product. Increased degradation temperatures for glycidylated lignin compared to unmodified lignin are described in literature for Kraft $\operatorname{lignin}^{[37]}$ as well as for Organosolv lignin. ${ }^{[42]}$

\subsection{Curing behavior of lignin reinforced epoxy resin}

The curing behavior of lignin reinforced epoxy resins was investigated via DSC studies. GOL and DGEBA were mixed with different lignin contents (0 to $50 \mathrm{wt} \%$ of the epoxy part, which is 0 to $42 \mathrm{wt} \%$ of the resin) and with a stoichiometric amount of IPDA. IPDA contains two amines - an aliphatic amine and a cycloaliphatic amine. Each amine can react with two epoxides. ${ }^{[43]}$ Thus, the molar ratio $\mathrm{r}$ is calculated as followed:

$r=\frac{f_{D G E B A} \cdot n_{\text {epoxy }}(D G E B A)+n_{\text {epoxy }}(G O L)}{f_{\text {amine }} \cdot n_{\text {amine }}}$

assuming that the functionality of IPDA $\left(f_{\text {amine }}\right)$ is equal to 4 and the functionality of DGEBA $\left(f_{\mathrm{DGEBA}}\right)$ is equal to 2 and the molar quantities of amine, DGEBA and GOL are assigned to $n_{\text {amine }}, n_{\text {epoxy }}(\mathrm{DGEBA})$ and $n_{\text {epoxy }}(\mathrm{GOL})$, respectively. Hence, a stoichiometric amount is defined by a ratio $r=1$ and usually leads to the highest thermomechanical properties. ${ }^{[44]}$

The recorded DSC traces for different lignin contents in the final resin are shown in Figure 2a. The heating revealed an exothermic peak with a starting point at $50{ }^{\circ} \mathrm{C}$, a maximum around $110{ }^{\circ} \mathrm{C}$ and end point at $220{ }^{\circ} \mathrm{C}$. The maximum shifts slightly to lower temperature, from $114{ }^{\circ} \mathrm{C}$ to $100{ }^{\circ} \mathrm{C}$, with increased lignin content of $0 \mathrm{wt} \%$ to $42 \mathrm{wt} \%$, respectively. A shoulder, observed at $150{ }^{\circ} \mathrm{C}$, decreases in intensity with increasing lignin content. The two peaks result from the difference in reactivity of the aliphatic and cyclo-aliphatic amino groups in IPDA. Cyclo-aliphatic amines are less reactive than aliphatic amines. ${ }^{[43]} \mathrm{A}$ reason for the decrease of the shoulder and the shift of the maximum with increased lignin content may be assigned to the remaining free hydroxy groups in lignin, that react with epoxides, hindering 
amines to react. Usually, the reaction of hydroxy groups with epoxides is only relevant if excess of epoxides are used. ${ }^{[43]}$ Yet, the sterically hindered structure of lignin may favor this reaction.

The residual reaction heat $\Delta H$ of the curing process is plotted against the lignin content in the final resin (Figure $2 \mathbf{b}$ ). $\Delta H$ in $\mathrm{J} / \mathrm{g}$ decreases with increasing lignin content from $385 \mathrm{~J} / \mathrm{g}$ for $0 \mathrm{wt} \%$ to $291 \mathrm{~J} / \mathrm{g}$ for $42 \mathrm{wt} \%$ (Figure $2 \mathrm{~b}$, black). The $\Delta H$ value for the lignin-free DGEBAIPDA resin is in the order of literature values. ${ }^{[4][45]}$ To the best of our knowledge, no residual heat reaction was analyzed for lignin-based epoxy resins in literature before. Simultaneously with the reaction heat decrease, the epoxy group content in the uncured mixture decreases from 5.88 to $4.54 \mathrm{mmol} / \mathrm{g}$. Considering this decrease, the reaction heat varies between 56 and $66 \mathrm{~J} / \mathrm{mmol}$ epoxide without significant increase or decrease tendency (Figure 2b, grey), indicating that the reactivity of the epoxides in glycidylated lignin and DGEBA is similar.
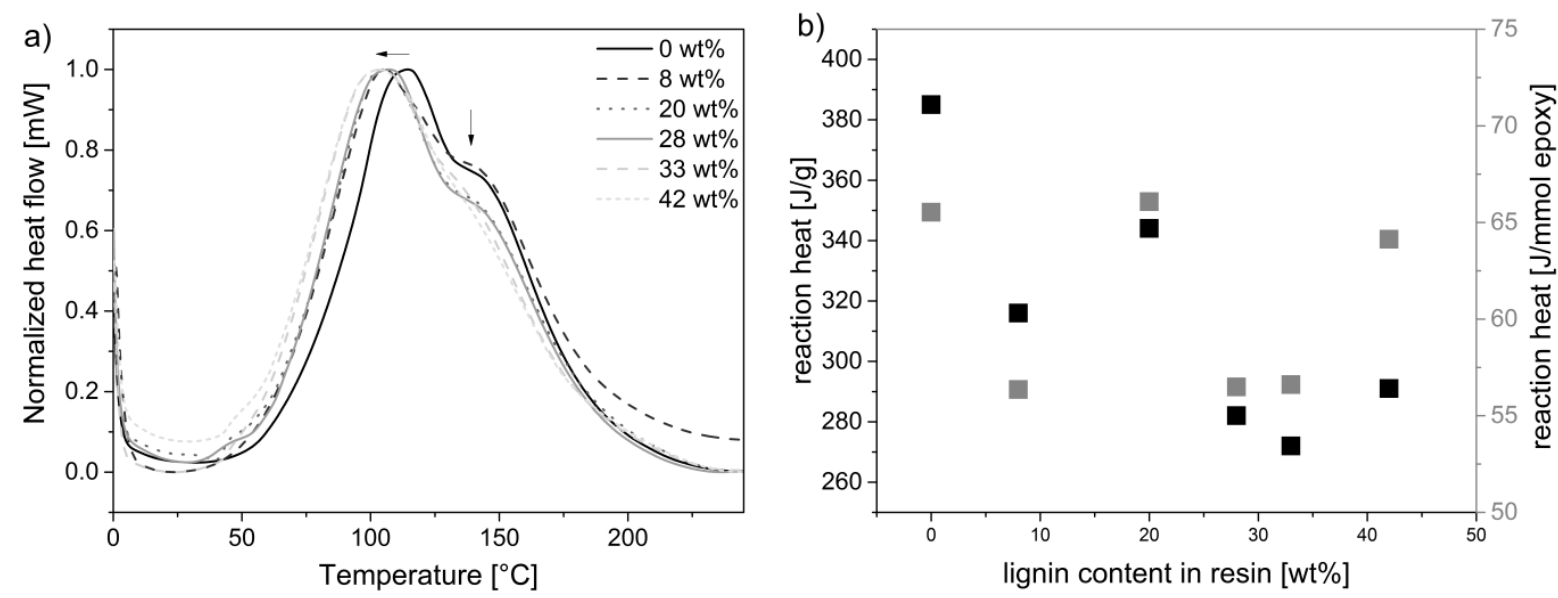

Figure 2. a) Normalized DSC traces of the curing of DGEBA-based epoxy resins (lignin content in $\mathrm{wt} \%$ ) at a heating rate of $10 \mathrm{~K} \mathrm{~min}^{-1}$; b) Reaction heat in $\mathrm{J} / \mathrm{g}$ (left axis, black) and in $\mathrm{J} / \mathrm{mmol}$ epoxy (right axis, grey).

\subsection{Structure of cured resins}

The final resins were cured in an oven at $70{ }^{\circ} \mathrm{C}$ for 1 hour and $120{ }^{\circ} \mathrm{C}$ for 2 hours in dog bone shape silicon molds to obtain specimens for direct structural and thermomechanical analyses. 
Comparison of the IR region between 500 and $1800 \mathrm{~cm}^{-1}$ for cured epoxy resins with uncured GOL shows the decrease of the epoxy C-O deformation vibration band for resins with lignin contents between 0 and 33 wt.\% (Figure 3). Only for the resin with 42 wt.\% GOL, the signal at $909 \mathrm{~cm}^{-1}$ is still present, indicating an inefficient curing process. Other changes in signal in Figure 3 can be explained as followed from the lowest wavenumber going to the highest. The broad signal at $<600 \mathrm{~cm}^{-1}$ results from skeletal C-C-C and H-C-C deformation vibrations mainly found in BPA and IPDA. The increased signal at $830 \mathrm{~cm}^{-1}$ should mainly result from the $\mathrm{C}-\mathrm{H}$ deformation vibration in the $1-4$ substituted $\mathrm{BPA} .{ }^{[46]} \mathrm{C}-\mathrm{N}$ stretching vibrations of tertiary amines contained in the cured resins show a typically bands at $1070 \mathrm{~cm}^{-1}$. The signal is overlaying with the symmetric C-O-C stretching vibration of aromatic ether and the C-H deformation vibration of 1-4 substituted BPA. Likewise, the new signal at $1180 \mathrm{~cm}^{-1}$ can be assigned to the deformation vibration of benzylic $\mathrm{C}-\mathrm{H}$ in BPA. Aromatic ether in BPA shows a broad band for the asymmetric C-O-C stretching vibration at $1233 \mathrm{~cm}^{-1}$. Due to the different origin of the $\mathrm{C}=\mathrm{C}$ stretching vibrations in the aromatic rings of BPA compared to GOL, two signals can be found, at 1581 and $1608 \mathrm{~cm}^{-1}$. All in all, the IR analysis showed the expected changes and proved the reaction of the epoxides. Only in the case of the highest applied lignin content, no efficient reaction was observed. The reason for inefficient reaction may be the poor miscibility of glycidylated lignin, DGEBA and IPDA due to the high solid-to-liquid ratio. Because of miscibility issues, no higher lignin contents were evaluated. 


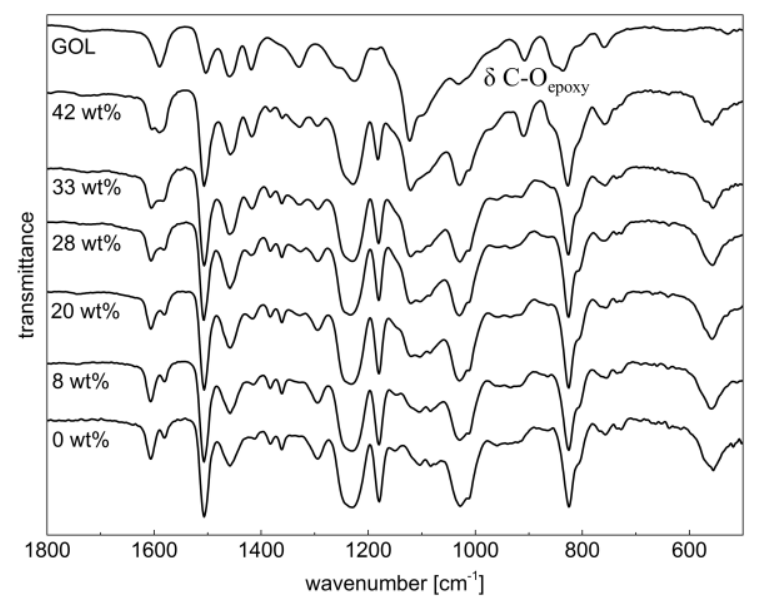

Figure 3. IR spectra (ATR) of glycidylated OL and cured epoxy resins.

SEM images with a magnitude of 5000 of the different resins are shown in Figure 4a-f. Cured resins were analyzed at a breaking edge. In all resins, the break caused the visible lamellar structure. Within the structure, homogeneity differences can be observed. The addition of lignin caused the formation of small dots, increasing in number with increasing GOL content. These dots are not observed in lignin-free epoxy resin (Figure 4a). With 8, 20 and 28 wt.\% GOL in the resin, the structure is mostly homogeneous (Figure $4 \mathbf{b}-\mathbf{d}$ ). In the resins with the highest lignin amounts of 33 and 42 wt.\% (Figure 4e and f), the agglomerations increased compared to lower lignin contents, indicating the partial incompatibility with the epoxy resin. This incompatibility can be explained by the inhomogeneous structure of lignin itself. Compared to literature results of SEM images for lignin-based epoxy resin, the herein discussed GOL still shows a better resin compatibility at higher lignin content: acetic acid lignin-based epoxy resin curing with DGEBA and triethylenetetramine led to higher agglomeration and even porosity if $50 \%$ of DGEBA were replaced. ${ }^{[26]}$ 

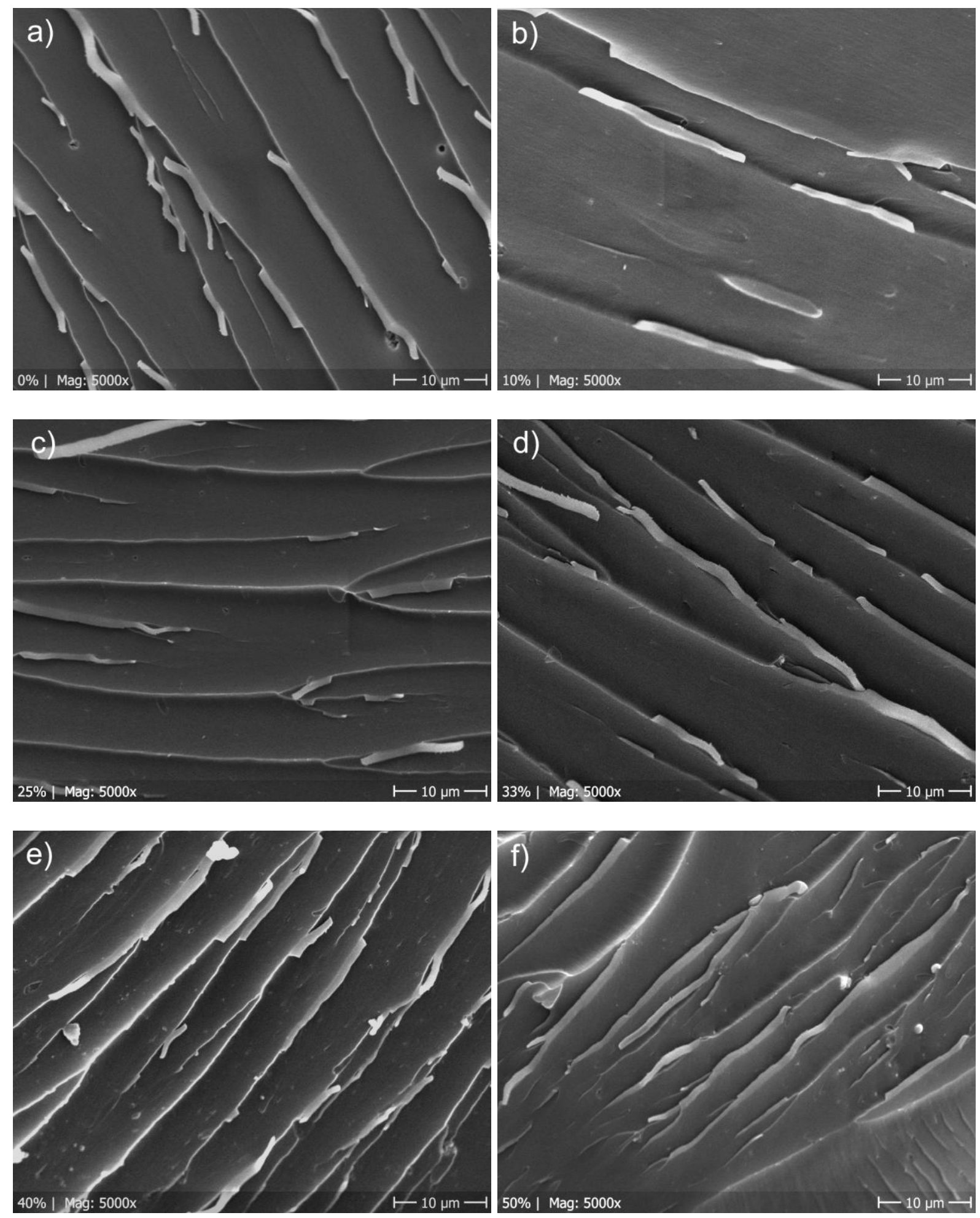

Figure 4. SEM images with 5000x magnification at the breaking edge of epoxy resins with a) $0 \mathrm{wt} \%$, b) $8 \mathrm{wt} \%$, c) $20 \mathrm{wt} \%$, d) $28 \mathrm{wt} \%$, e) $33 \mathrm{wt} \%$, and f) $42 \mathrm{wt} \%$ GOL in the final resin (the shown percentages indicate the DGEBA replaced by GOL). 


\subsection{Thermomechanical properties of epoxy resins from DGEBA and glycidylated lignin}

The influence of the lignin content on thermomechanical properties was studied by TGA, DSC, DMA and stress/strain measurements. The degradation temperature for $5 \%$ weight loss $\left(T_{\mathrm{d} 5 \%}\right)$, measured via TGA, decreases from $334{ }^{\circ} \mathrm{C}$ to $284{ }^{\circ} \mathrm{C}$, with increasing lignin content (Figure 5a). Regarding the weight loss trace (Figure 5b), the degradation temperature for $30 \%$ weight loss $\left(T_{\mathrm{d} 30 \%}\right)$ is in a narrower region between 338 and $350{ }^{\circ} \mathrm{C}$. Likewise, the lignin-free composite is the most stable resin. The heat resistant index $T_{\mathrm{s}}$, calculated from Equation (2), varies between 168 and $156^{\circ} \mathrm{C}$ and thus, also decreases with increasing lignin content. Although this initial degradation starts at higher temperatures for lignin-free resin, the second degradation step starts later for lignin-containing resins. Earlier initial degradation for lignin-containing resins coincides with observations for other lignin-DGEBA ${ }^{[26]}$ and lignin epoxy resins without second epoxy compound. ${ }^{[29,31]}$ The first degradation, as discussed for the unmodified and glycidylated lignin, occurs mainly between 280 and $350{ }^{\circ} \mathrm{C}$ and is most significant for all samples. A second degradation step from further cracking processes occurs between 500 and $600{ }^{\circ} \mathrm{C}$. Since this behavior hardly changes with the addition of lignin, the similar characteristics of linkages in lignin-based and lignin-free epoxy material is exhibited. 

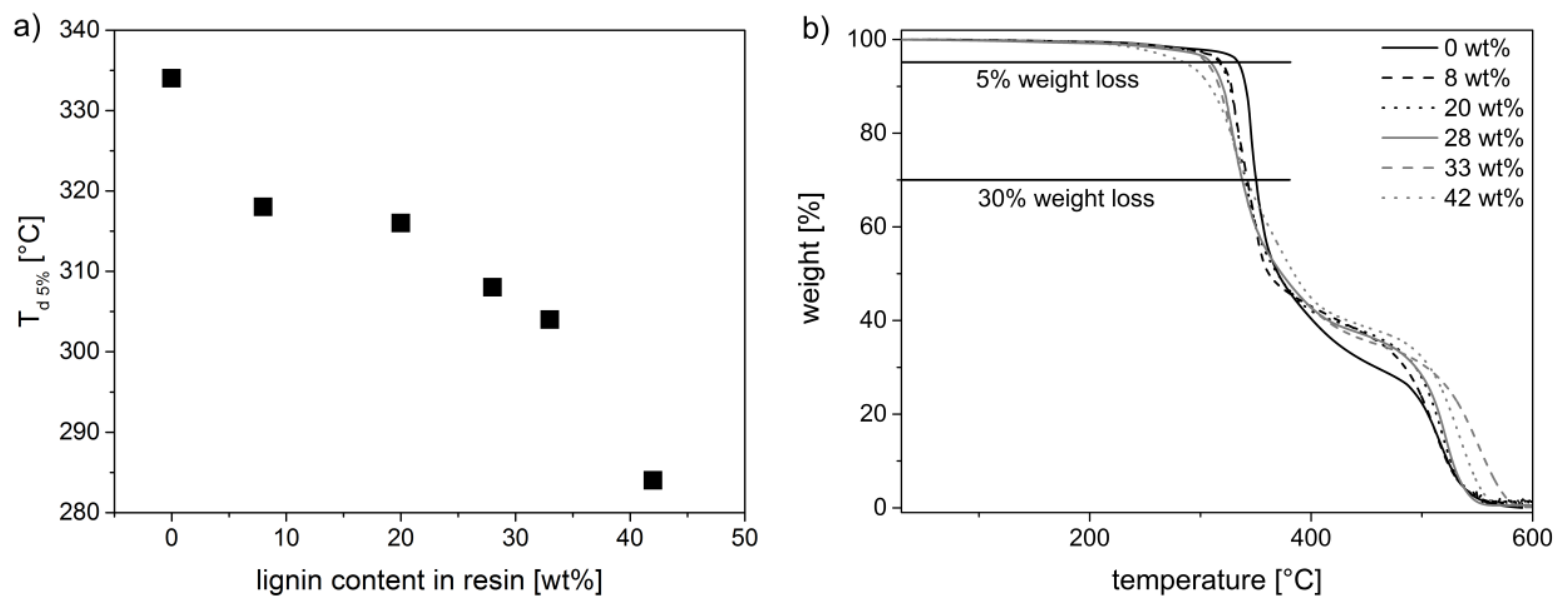

Figure 5. a) Degradation temperature for 5\% mass loss for the cured resins with different lignin content obtained from TGA; b) Comparison of the weights loss during TGA for the different cured resins at a heating rate of $5 \mathrm{~K} \mathrm{~min}^{-1}$.

The glass transition temperature $\left(T_{\mathrm{g}}\right)$ was evaluated from DSC and DMA measurements (Figure 6). $T_{\mathrm{g}}$ increases from $150{ }^{\circ} \mathrm{C}$ to $168^{\circ} \mathrm{C}$ (DSC), with increasing lignin content from 0 to $33 \mathrm{wt} \%$. DMA results show the same tendency, with $T_{\mathrm{g}}$ values ranging from 123 to $138{ }^{\circ} \mathrm{C}$. Going to $42 \mathrm{wt} \%$ lignin, $T_{\mathrm{g}}$ drops to $132{ }^{\circ} \mathrm{C}$ (for DMA; no $T_{\mathrm{g}}$ observed in DSC). An increased $T_{\mathrm{g}}$ may indicate a higher cross-linking density in the resin. ${ }^{[43]}$ Glycidylated lignin contains free hydroxy groups that could react with epoxides, leading to higher cross-linking. On the other hand, the inhomogeneous structure of lignin may lead to a more rigid structure, also leading to a higher $T_{\mathrm{g}}$. 


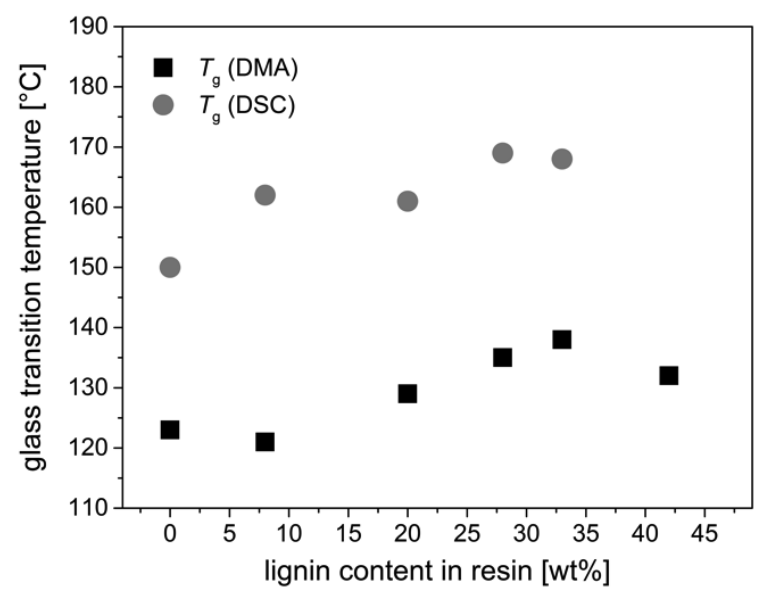

Figure 6. Glass transition temperature of the cured resins with different lignin content obtained from DSC (grey) and DMA (black).

Mechanical properties of the resins from stress/strain and DMA measurements are shown in Table 2. Young's modulus $E$ varied between 1.82 and $1.88 \mathrm{GPa}$. This is within expectations for DGEBA-based epoxy resins. In literature, values around $3 \mathrm{GPa}$ are reported. ${ }^{[47,48]} 10 \%$ replacement of DGEBA by lignin led to a drop of $E$ from 1.88 to $1.82 \mathrm{GPa}$. A low lignin amount seems to add flexibility to the resin, which may be explained by lower epoxy density. Going to a higher lignin content (50 wt\% of DGEBA were replaced by GOL), the product became more rigid ( $E$ increases), leading to a brittle material that could not be fixed to the apparatus without breaking immediately. The increase of $E$, accompanied by higher stiffness, results from the inhomogeneous structure of lignin. This observation coincides with the increasing glass transition with increasing lignin content. The storage modulus $E^{\prime}$ in the glassy state obtained from DMA was in a similar region and showed the same tendency as $E$. Likewise, the observed decrease in the elongation at break for higher GOL content indicates a higher stiffness (Table 2, column 3). The cross-linking density, calculated from Equation (3) from the storage modulus $E^{\prime}$ in the rubbery phase and $T_{\alpha}$, showed an increase with growing lignin content, as already estimated from the glass transition. BPA-IPDA resins exhibited a cross-linking density $v$ of $9.9 \cdot 10^{3} \mathrm{~mol} \mathrm{~m}^{-3}$ and the resins with 28 and $33 \mathrm{wt} \%$ lignin showed densities of 23 and $22 \cdot 10^{3} \mathrm{~mol} \mathrm{~m}^{-3}$, respectively. Only for the resin with the highest lignin 
content of $42 \mathrm{wt} \%$, a decrease was observed. The already discussed for other analytics, the GOL is poorly miscible with DGEBA and IPDA if the lignin-content is to high und thus, no satisfying results can be obtained. The optimum can be found for a resin with 33 wt $\%$ of GOL.

Table 2. Values for mechanical properties and swelling test of cured lignin-BPA-IPDA-based epoxy resins

\begin{tabular}{|c|c|c|c|c|c|c|}
\hline $\begin{array}{l}\text { Lignin } \\
\text { content } \\
{[\%]}\end{array}$ & $\begin{array}{l}\text { Young's } \\
\text { modulus } \\
{[\mathrm{GPa}]}\end{array}$ & $\begin{array}{l}\text { Elongation } \\
\text { at break } \\
{[\%]}\end{array}$ & $\begin{array}{l}E^{\prime}(36 \\
\left.{ }^{\circ} \mathbf{C}\right) \\
{[\mathbf{G P a}]}\end{array}$ & $\begin{array}{l}E^{\prime}(210 \\
\left.{ }^{\circ} \mathrm{C}\right) \\
{[\mathbf{G P a}]}\end{array}$ & $\begin{array}{l}\boldsymbol{T}_{\alpha} \\
{\left[{ }^{\circ} \mathbf{C}\right]}\end{array}$ & $\begin{array}{l}v \\
{\left[10^{3} \mathrm{~mol} \mathrm{~m}^{-3}\right]}\end{array}$ \\
\hline 0 & 1.88 & 3.0 & 1.37 & 0.036 & 137 & 9.8 \\
\hline 8 & 1.82 & 2.3 & 2.02 & 0.048 & 138 & 13 \\
\hline 20 & 1.84 & 2.0 & 1.95 & 0.055 & 148 & 15 \\
\hline 28 & 1.92 & 1.5 & 1.9 & 0.087 & 157 & 23 \\
\hline 33 & 1.90 & 1.70 & 1.84 & 0.083 & 159 & 22 \\
\hline 42 & \multicolumn{2}{|c|}{$\begin{array}{l}\text { samples broke during } \\
\text { traction test preparation }\end{array}$} & 1.07 & 0.033 & 144 & 8.8 \\
\hline
\end{tabular}

\subsection{Swelling properties}

The swelling of the cured resins was performed in THF as described in section 2.3.10 in the experimental part. Swelling and soluble part were calculated from Equation (4) and (5), respectively, and summarized for all lignin contents (Table 3). A lower percentage of swelling usually indicates a higher cross-linking density, as distances within the network are smaller and thus, solvent absorption is lower as well. Swelling decreased from 7 to $1 \%$, in tandem with increased lignin content from 0 to $20 \mathrm{wt} \%$. This implies a higher cross-linking with a lignin content of $20 \mathrm{wt} \%$. Higher lignin contents resulted in increased swelling up to $10 \%$ for 42 wt $\%$ GOL. The soluble part remained constantly low and then increased with increased lignin content from $0 \%$ soluble part for 0,8 or $20 \mathrm{wt} \%$ lignin content to $6 \%$ soluble part for $42 \mathrm{wt} \%$ lignin content. As estimated from $T_{\mathrm{g}}$ and calculated from DMA, the swelling 
test revealed the same tendency. The addition of lignin initially stabilized the epoxy resin product due to a higher cross-linking, but led to poor network formation with lignin content of $42 \mathrm{wt} \%$.

Table 3. Swelling properties of cured epoxy resins

\begin{tabular}{lcccccc}
\hline $\begin{array}{l}\text { Lignin content } \\
{[\%]}\end{array}$ & $\mathbf{0}$ & $\mathbf{8}$ & $\mathbf{2 0}$ & $\mathbf{2 8}$ & $\mathbf{3 3}$ & $\mathbf{4 2}$ \\
\hline $\begin{array}{l}\text { Swelling } \\
{[\%]}\end{array}$ & 7 & 3 & 1 & 3 & 2 & 10 \\
$\begin{array}{l}\text { Soluble part } \\
{[\%]}\end{array}$ & 0 & 0 & 0 & 1 & 1 & 6
\end{tabular}

\section{Conclusion}

Epoxy resins were synthesized from glycidylated organosolv lignin and DGEBA in different weight ratios and IPDA as common industrial hardener. Under the chosen conditions, lignin could not completely replace BPA. However, in the applied weight ratios, lignin revealed reinforcing properties with weight percentages up to $33 \%$ in the final product. DSC curing verified the replacement suitability, indicating a similar reactivity for lignin- and BPA-based epoxides. The completed reaction in the final resins was verified by the disappearance of the epoxy stretching vibration band in IR spectroscopy. In addition, thermal and mechanical analysis revealed that lignin-based resins have a higher cross-linking density compared to pure DGEBA-IPDA resin, if 10 to $40 \mathrm{wt} \%$ of DGEBA was replaced. Although, thermal stability decreases with increasing lignin content, degradation temperatures are still in an applicable region for epoxy resins. Due to inhomogeneity in lignin itself, inhomogeneity in the produced resins was observed if the renewable content is increased but can still be considered low. All in all, it could be shown that GOL is suitable for partial replacement of DGEBA in an industrial relevant epoxy resin.

\section{Supporting Information}

Supporting Information is available from the Wiley Online Library or from the author. 


\section{Appendix}

Acknowledgements: LCO is thankful for a PhD fellowship from the Deutsche Bundesstiftung Umwelt (German Federal Environmental Foundation, DBU). The authors would like to thank colleagues at the Thünen Institute of Wood Research (Hamburg, Germany) for the performance of the Organosolv pulping and the provision of the materials. We thank Gérard Dimier at LCPO for the performance of DMA measurements and Ingrid Zeller in the group of Prof. Deutschmann at KIT for SEM performance.

Received: Month XX, XXXX; Revised: Month XX, XXXX; Published online:

((For PPP, use "Accepted: Month XX, XXXX" instead of "Published online")); DOI: 10.1002/marc.((insert number)) ((or ppap., mabi., macp., mame., mren., mats.))

Keywords: biopolymers, crosslinking, curing of polymers, epoxy, renewable resources

[1] T. Geens, L. Goeyens, A. Covaci, Int. J. Hyg. Environ. Health 2011, 214, 339.

[2] M. Bondesson, J. Jönsson, I. Pongratz, N. Olea, J.-P. Cravedi, D. Zalko, H. Håkansson, K. Halldin, D. Di Lorenzo, C. Behl, D. Manthey, P. Balaguer, B. Demeneix, J.-B. Fini, V. Laudet, J.-A. Gustafsson, Reprod. Toxicol. 2009, 28, 563.

[3] H. H. Le, E. M. Carlson, J. P. Chua, S. M. Belcher, Toxicol. Lett. 2008, 176, 149.

[4] L. N. Vandenberg, R. Hauser, M. Marcus, N. Olea, W. V. Welshons, Reprod. Toxicol. 2007, 24, 139.

[5] J. H. Kang, F. Kondo, Y. Katayama, Toxicology 2006, 226, 79.

[6] E. C. Dodds, W. Lawson, Nature 1936, 137, 996.

[7] Merchant Research \& Consulting: World BPA Production, https://mcgroup.co.uk/, accessed: July, 2016.

[8] R. Whetten, R. Sederoff, Plant Cell 1995, 7, 1001. 
[9] J. Zakzeski, P. C. A. Bruijnincx, A. L. Jongerius, B. M. Weckhuysen, Chem. Rev. 2010, $110,3552$.

[10] M. Kleinert, T. Barth, Chem. Eng. Technol. 2008, 31, 736.

[11] M. P. Pandey, C. S. Kim, Chem. Eng. Technol. 2011, 34, 29.

[12] M. Fache, A. Viola, R. Auvergne, B. Boutevin, S. Caillol, Eur. Polym. J. 2015, 68, 526.

[13] M. Fache, R. Auvergne, B. Boutevin, S. Caillol, Eur. Polym. J. 2015, 67, 527.

[14] M. Fache, B. Boutevin, S. Caillol, Green Chem. 2016, 18, 712.

[15] C. François, S. Pourchet, G. Boni, S. Fontaine, Y. Gaillard, V. Placet, M. V. Galkin, A. Orebom, J. Samec, L. Plasseraud, RSC Adv. 2016, 6, 68732.

[16] C. I. Simionescu, V. Rusan, M. M. Macoveanu, G. Cazacu, R. Lipsa, C. Vasile, A. Stoleriu, A. Ioanid, Compos. Sci. Technol. 1993, 48, 317.

[17] D. Feldman, D. Banu, A. Natansohn, J. Wang, J. Appl. Polym. Sci. 1991, 42, 1537.

[18] D. Feldman, D. Banu, C. Luchian, J. Wang, J. Appl. Polym. Sci. 1991, 42, 1307.

[19] Y. Nonaka, B. Tomita, Y. Hatano, Holzforschung 1997, 51, 183.

[20] D. Feldman, M. Khoury, J. Adhes. Sci. Technol. 1988, 2, 107.

[21] Q. F. Yin, M. W. Di, Adv. Compos. Mater. Pts 1-3 2012, 482-484, 1959.

[22] G.-H. Delmas, B. Benjelloun-Mlayah, Y. Le Bigot, M. Delmas, J. Appl. Polym. Sci. 2013, 127, 1863.

[23] S. Hirose, T. Hatakeyama, H. Hatakeyama, Macromol. Symp. 2003, 197, 157.

[24] T. Malutan, R. Nicu, V. I. Popa, BioResources 2008, 3, 1371.

[25] A. Singh, K. Yadav, A. Kumar Sen, Am. J. Polym. Sci. 2012, 2, 14.

[26] P. Feng, F. Chen, BioResources 2012, 7, 2860.

[27] F. Ferdosian, Z. Yuan, M. Anderson, C. C. Xu, J. Anal. Appl. Pyrolysis 2016, 119, 124.

[28] F. Ferdosian, Y. Zhang, Z. Yuan, M. Anderson, C. Xu, Eur. Polym. J. 2016, 82, 153.

[29] C. Sasaki, M. Wanaka, H. Takagi, S. Tamura, C. Asada, Y. Nakamura, Ind. Crops 
Prod. 2013, 43, 757.

[30] J. Xin, M. Li, R. Li, M. P. Wolcott, J. Zhang, ACS Sustain. Chem. Eng. 2016, 4, 2754.

[31] C. Asada, S. Basnet, M. Otsuka, C. Sasaki, Y. Nakamura, Int. J. Biol. Macromol. 2015, $74,413$.

[32] A. Granata, D. S. Argyropoulos, J. Agric. Food Chem. 1995, 43, 1538.

[33] Y. C. Chiu, I. C. Chou, W. C. Tseng, C. C. M. Ma, Polym. Degrad. Stab. 2008, 93, 668.

[34] T. Iijima, N. Yoshioka, M. Tomoi, Eur. Polym. J. 1992, 28, 573.

[35] P. J. Flory, Polymer 1979, 20, 1317.

[36] L. C. Over, M. A. R. Meier, Green Chem. 2016, 18, 197.

[37] N.-E. El Mansouri, Q. Yuan, F. Huang, BioResources 2011, 6, 2647.

[38] M. G. González, J. C. Cabanelas, J. Baselga, Infrared Spectroscopy - Materials Science, Engineering and Technology, INTECH 2012, Ch. 13.

[39] H. El-Saied, A. A. M. A. Nada, Polym. Degrad. Stab. 1993, 40, 417.

[40] R. Sun, J. Tomkinson, G. Lloyd Jones, Polym. Degrad. Stab. 2000, 68, 111.

[41] H. Yoshida, R. Mörck, K. P. Kringstad, Holzforschung 1987, 41, 171.

[42] F. Ferdosian, Z. Yuan, M. Anderson, C. C. Xu, J. Sci. Technol. For. Prod. Process. 2012, 2,11 .

[43] R. Auvergne, S. Caillol, G. David, B. Boutevin, J. P. Pascault, Chem. Rev. 2014, 114, 1082.

[44] J. Galy, A. Sabra, J. Pascault, Polym. Eng. Sci. 1986, 26, 1514.

[45] M. Chrysanthos, J. Galy, J.-P. Pascault, Polymer 2011, 52, 3611.

[46] A. Cherdoud-Chihani, M. Mouzali, M. J. M. Abadie, J. Appl. Polym. Sci. 2003, 87, 2033.

[47] A. A. Roche, J. Bouchet, Application of Fracture Mechanics to Polymers, Adhesives and Composites, 1st ed., Elsevier Ltd and ESIS 2004, pp. 249-257. 
[48] T. Okabe, Y. Oya, K. Tanabe, G. Kikugawa, K. Yoshioka, Eur. Polym. J. 2016, 80, 78.

Epoxy resins from glycidylated organosolv lignin, diglycidyl ether of bisphenol A (DGEBA) and isophorone diamine (IPDA) are discussed for lignin contents between 0 and $42 \mathrm{wt} \%$. Lignin-based resins show higher cross-linking densities that lead to higher glass transition, lower swelling percentages and increased stiffness if compared to non-lignin resins.

L. C. Over, E. Grau, S. Grelier, M. A. R. Meier,* H. Cramail*

Synthesis and characterization of epoxy resins from glycidylated organosolv lignin and bisphenol A

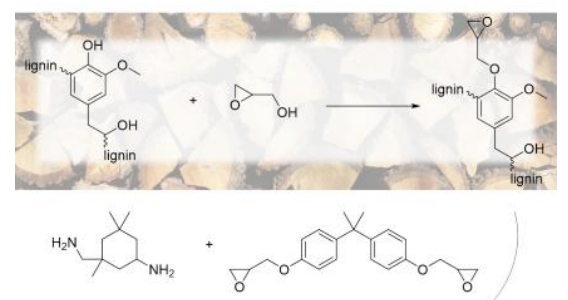

1111 
((Supporting Information should be included here for submission only; for publication, please provide Supporting Information as a separate PDF file.))

Copyright WILEY-VCH Verlag GmbH \& Co. KGaA, 69469 Weinheim, Germany, 2013.

Supporting Information

for Macromol. Chem. Phys, DOI: 10.1002/macp.2013\#\#\#\#\#

Synthesis and characterization of epoxy resins from glycidylated organosolv lignin and bisphenol A

Lena Charlotte Over, Etienne Grau, Stéphane Grelier, Henri Cramail, Michael A. R. Meier*

\section{Characterization of glycidylated lignin}

${ }^{1}$ H NMR

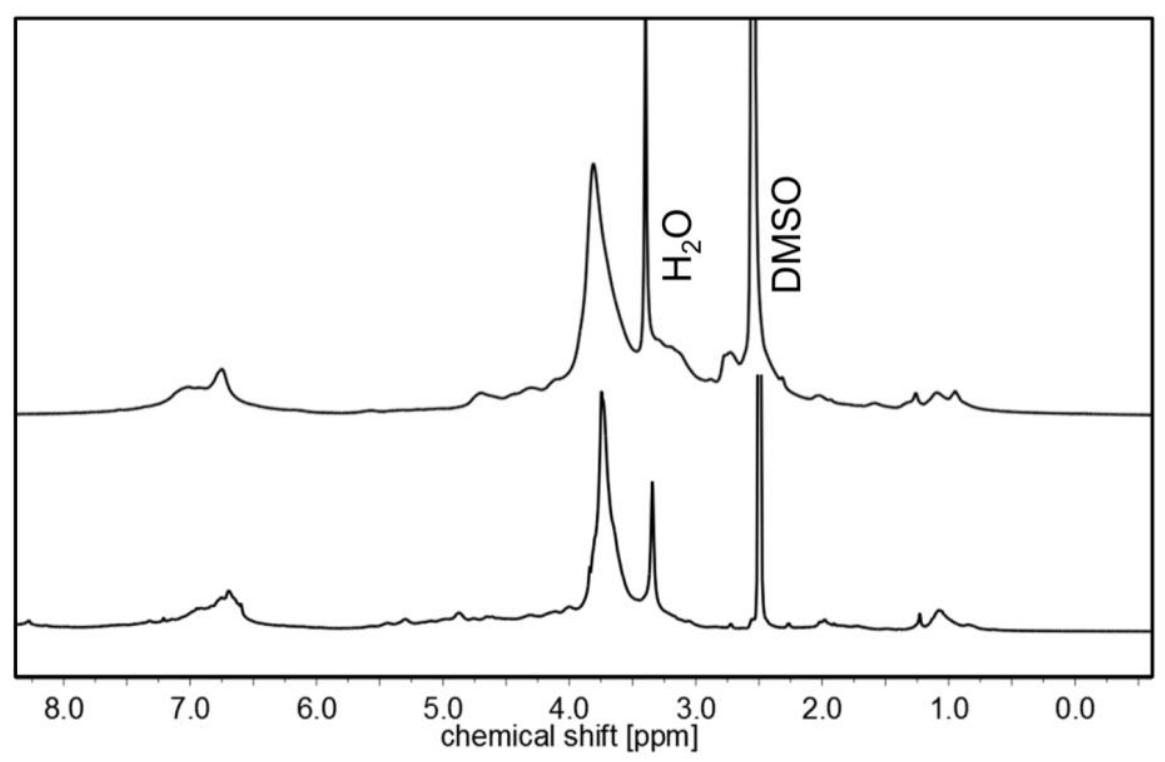




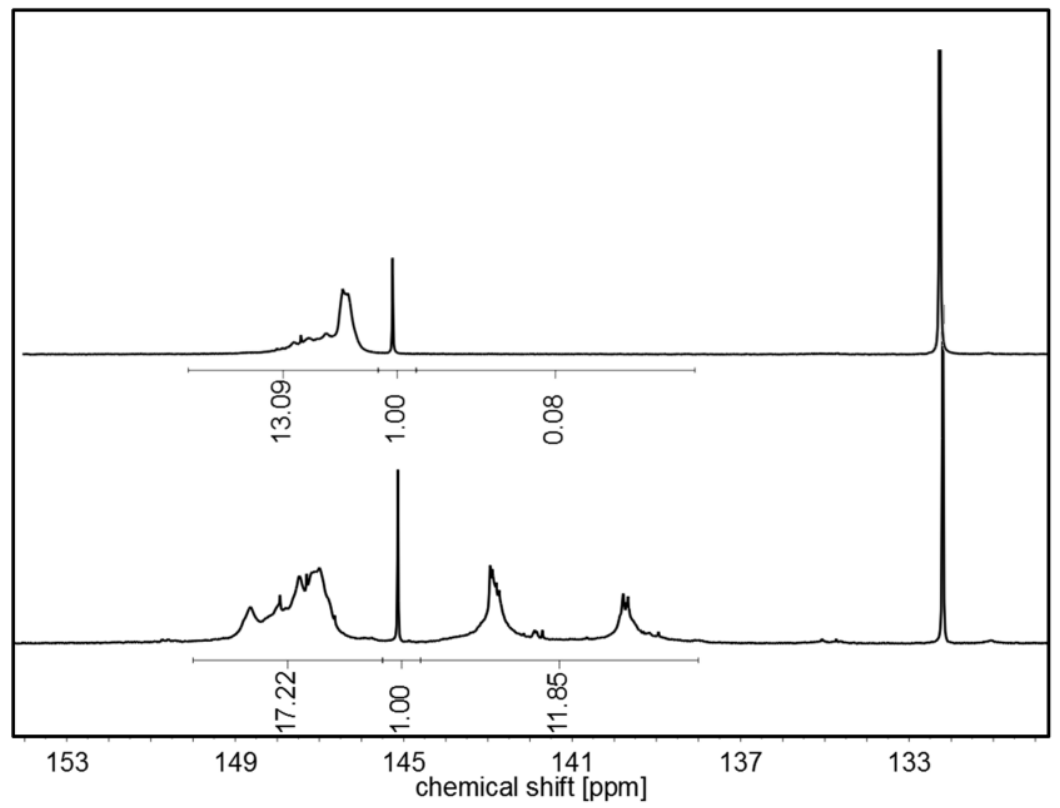

Figure $7 .{ }^{31} \mathrm{P}$ NMR spectra of unmodified organsolv lignin (top) and glycidylated lignin (bottom).

\section{Thermogravimetric analysis (TGA)}

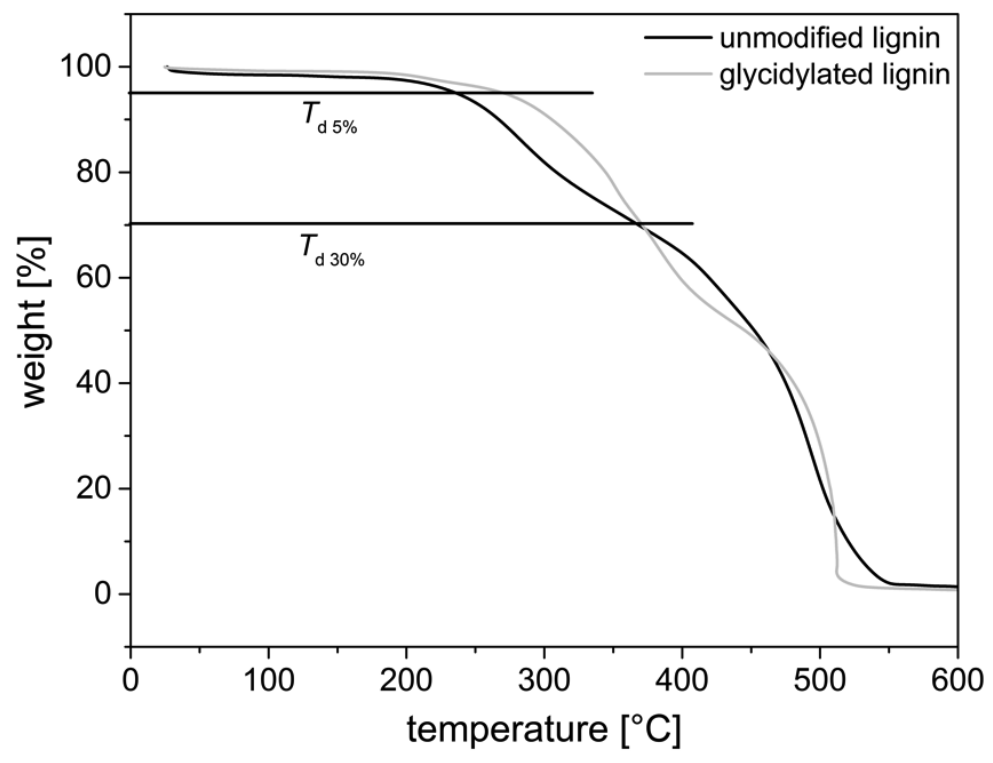

Figure 8. TGA traces of unmodified and glycidylated lignin. 


\section{Characterization of the resin}

\section{Thermogravimetric analysis}

Table 4. Thermogravimetric analysis: degradation temperature for epoxy resins with different lignin contents.

\begin{tabular}{llll}
\hline $\begin{array}{l}\text { Lignin content } \\
{[\%]}\end{array}$ & $\begin{array}{l}\boldsymbol{T}_{\mathbf{d} 5 \%} \\
{\left[{ }^{\circ} \mathbf{C}\right]}\end{array}$ & $\begin{array}{l}\boldsymbol{T}_{\mathbf{d ~ 3 0 \%}} \\
{\left[{ }^{\circ} \mathbf{C}\right]}\end{array}$ & $\begin{array}{l}\boldsymbol{T}_{\mathbf{S}} \\
{\left[{ }^{\circ} \mathbf{C}\right]}\end{array}$ \\
\hline unmodified lignin & 233 & 265 & 153 \\
glycidylated lignin & 269 & 371 & 162 \\
0 & 334 & 350 & 168 \\
8 & 318 & 343 & 163 \\
20 & 316 & 341 & 162 \\
28 & 308 & 338 & 160 \\
33 & 304 & 338 & 159 \\
42 & 284 & 342 & 156
\end{tabular}


Differential scanning calorimetry (DSC)

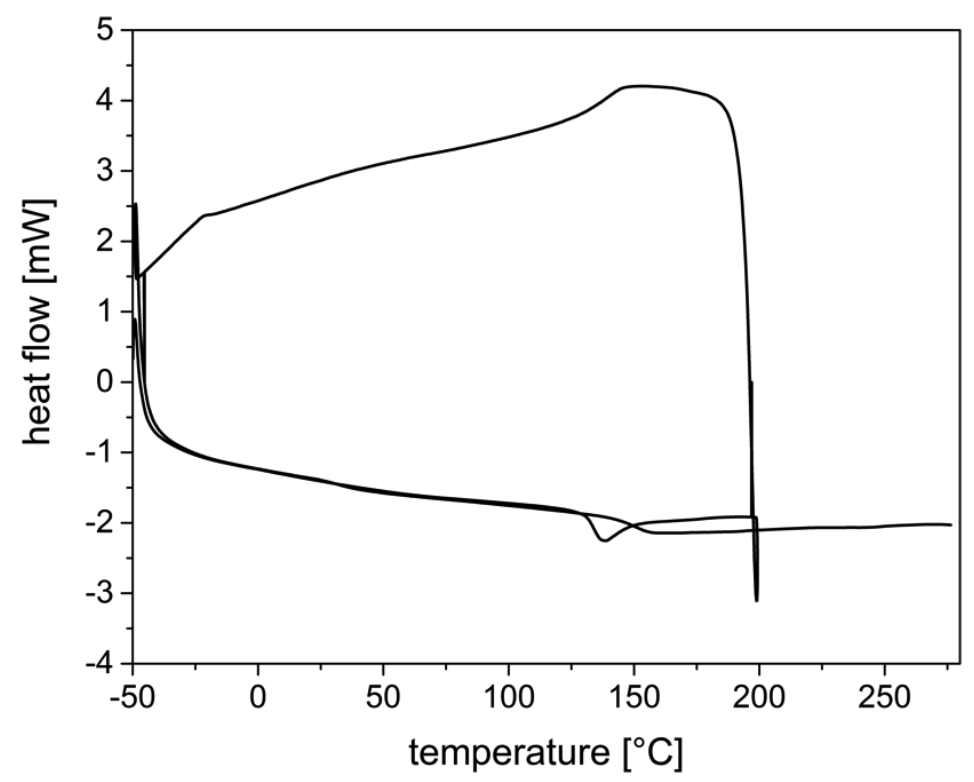

Figure 9. DSC trace for cured epoxy resin from DGEBA and IPDA (0 wt $\%$ lignin).

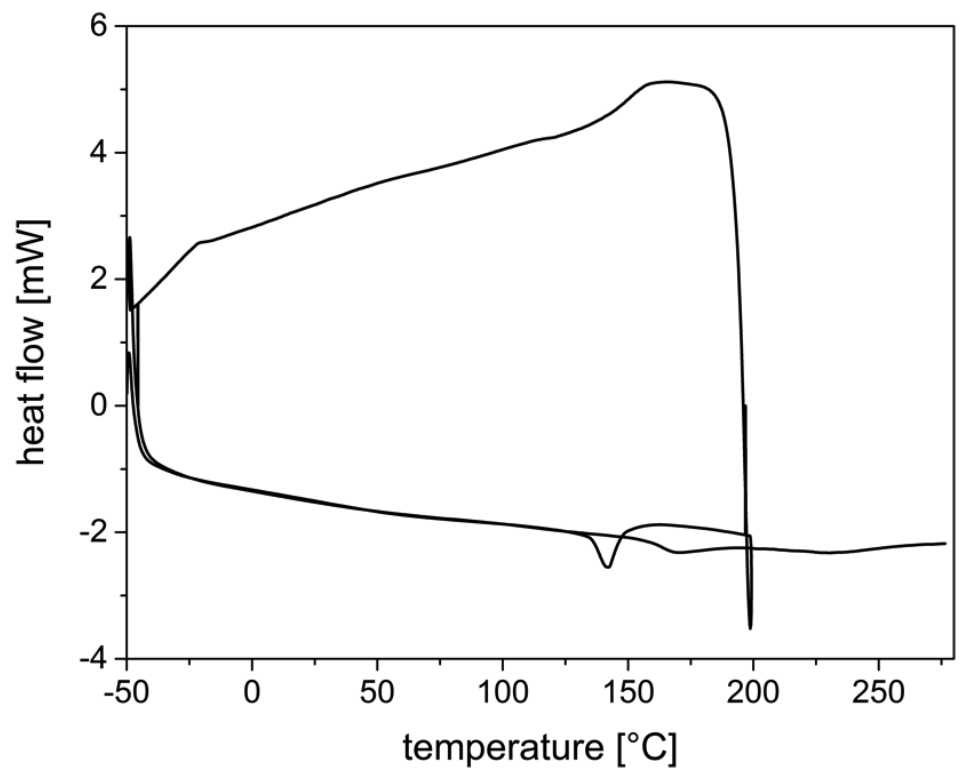

Figure 10. DSC trace for cured epoxy resin with $8 \mathrm{wt} \%$ glycidylated lignin. 


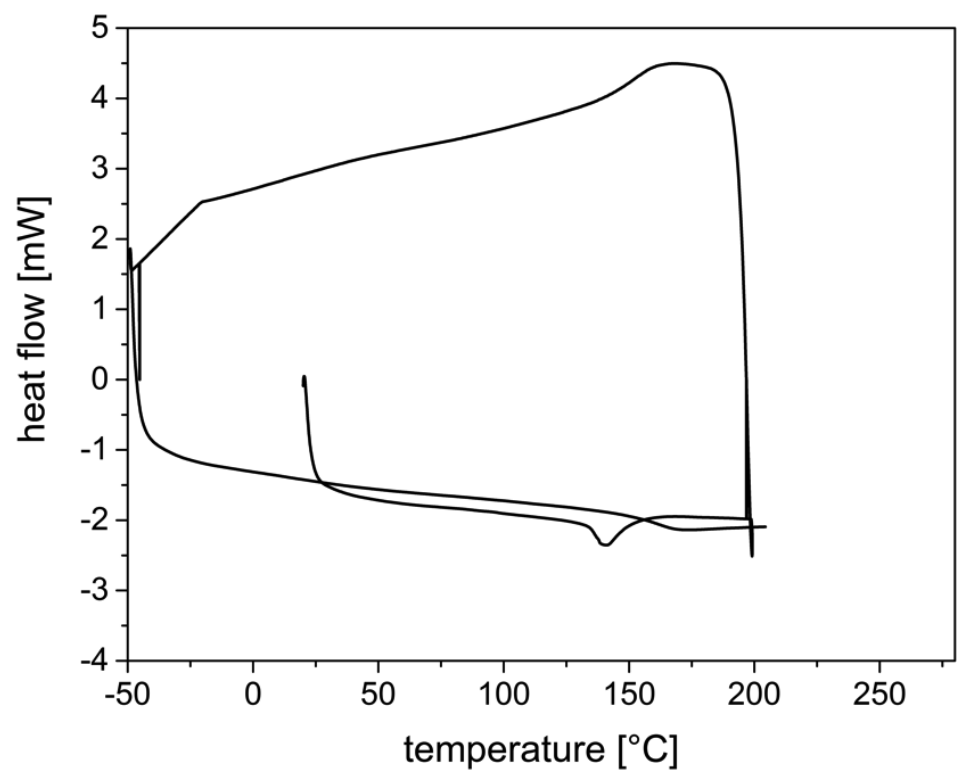

Figure 11. DSC trace for cured epoxy resin with $20 \mathrm{wt} \%$ glycidylated lignin.

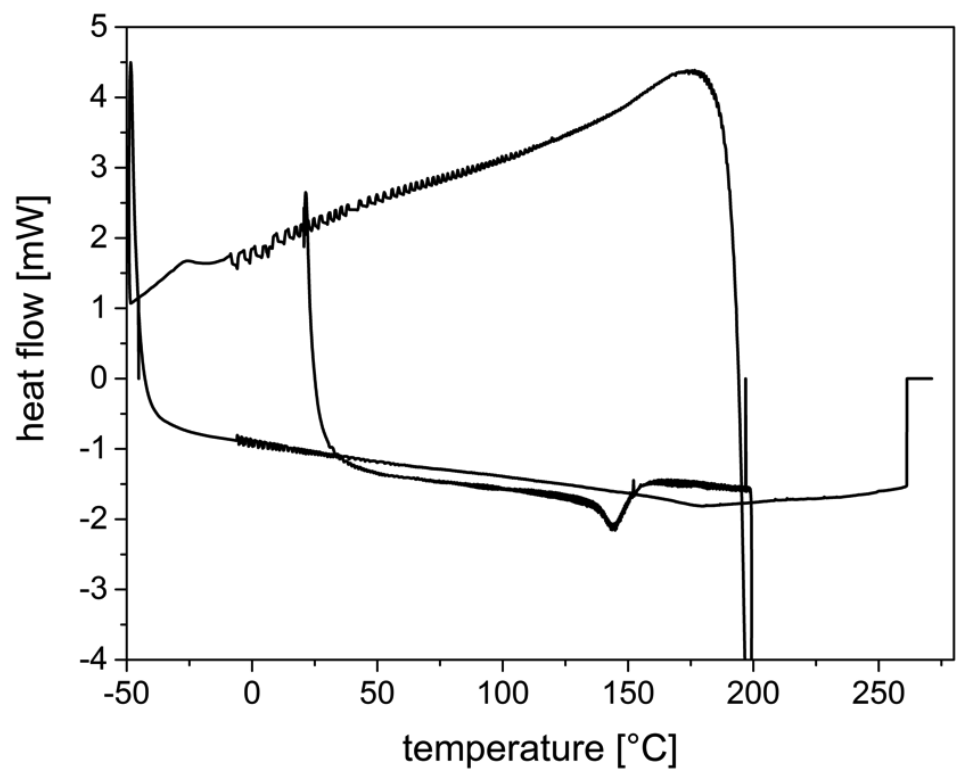

Figure 12. DSC trace for cured epoxy resin with $28 \mathrm{wt} \%$ glycidylated lignin. 


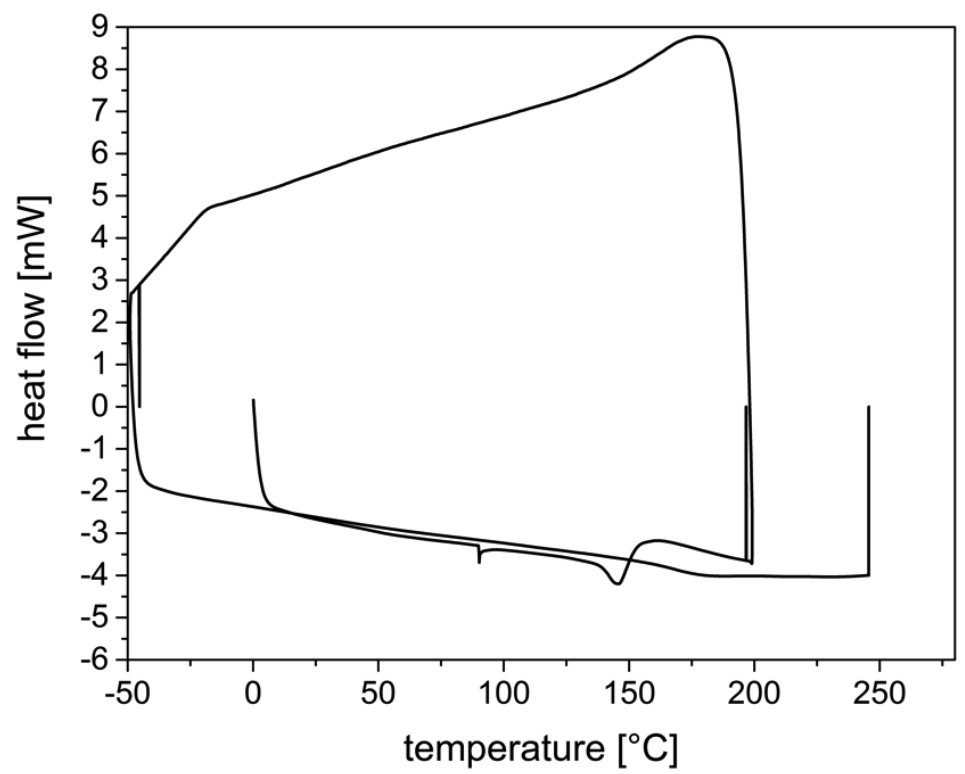

Figure 13. DSC trace for cured epoxy resin with $33 \mathrm{wt} \%$ glycidylated lignin.

\section{Dynamic mechanical analysis (DMA)}

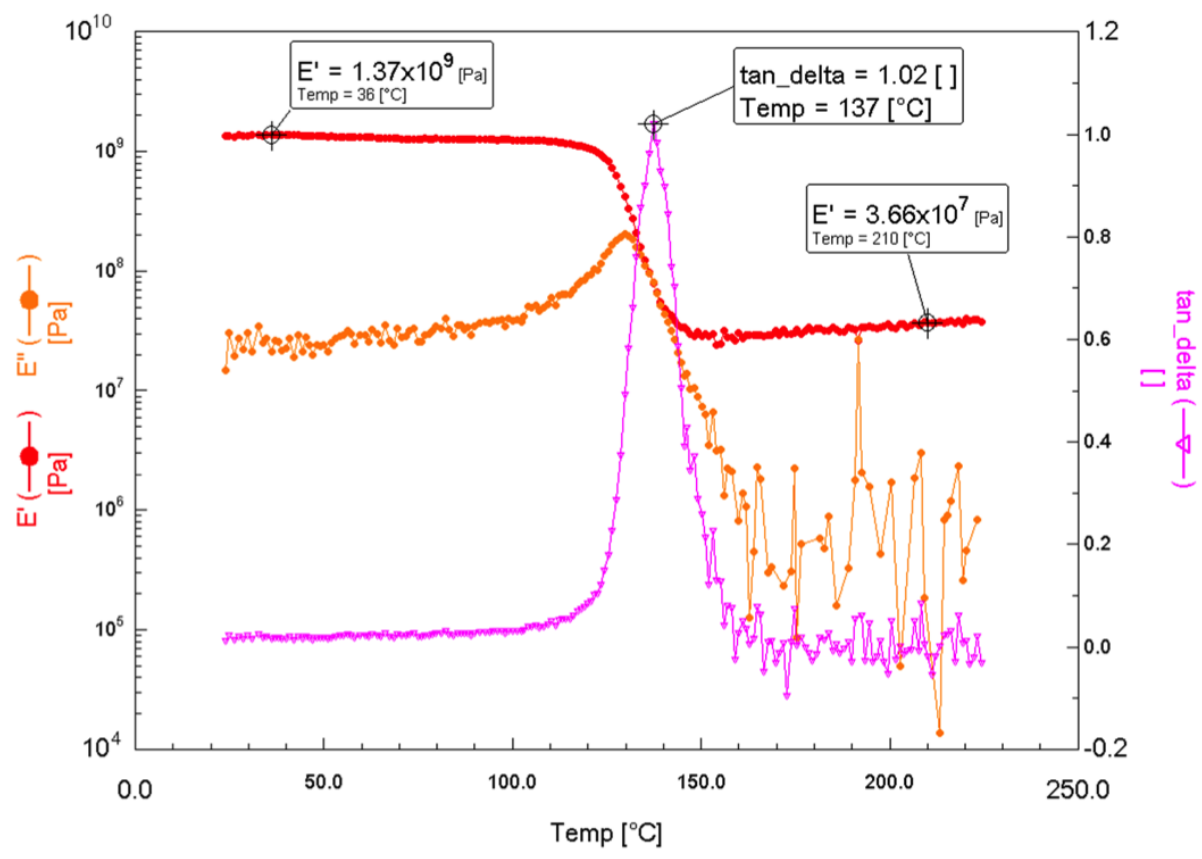

Figure 14. Storage modulus (E'), loss modulus (E') and tan delta from DMA of lignin-based epoxy resin from DGEBA-IPDA without lignin with 3 point bending mode, with a frequency of $1 \mathrm{~Hz}$, an initial force of $0.5 \mathrm{~N}$ and a strain sweep of $0.01 \%$. 


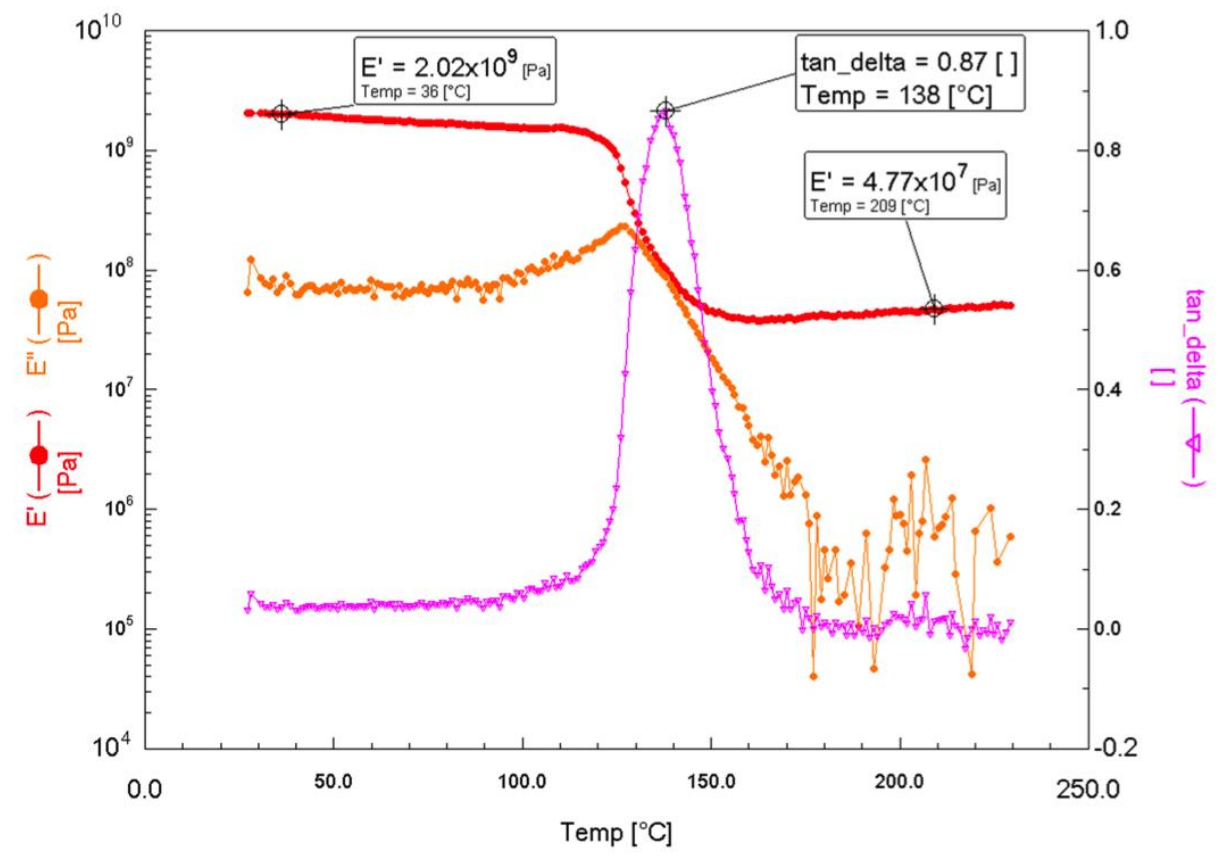

Figure 15. Storage modulus (E'), loss modulus (E') and tan delta from DMA of lignin-based epoxy resin with $8 \mathrm{wt} \%$ lignin with 3 point bending mode, with a frequency of $1 \mathrm{~Hz}$, an initial force of $0.5 \mathrm{~N}$ and a strain sweep of $0.01 \%$.

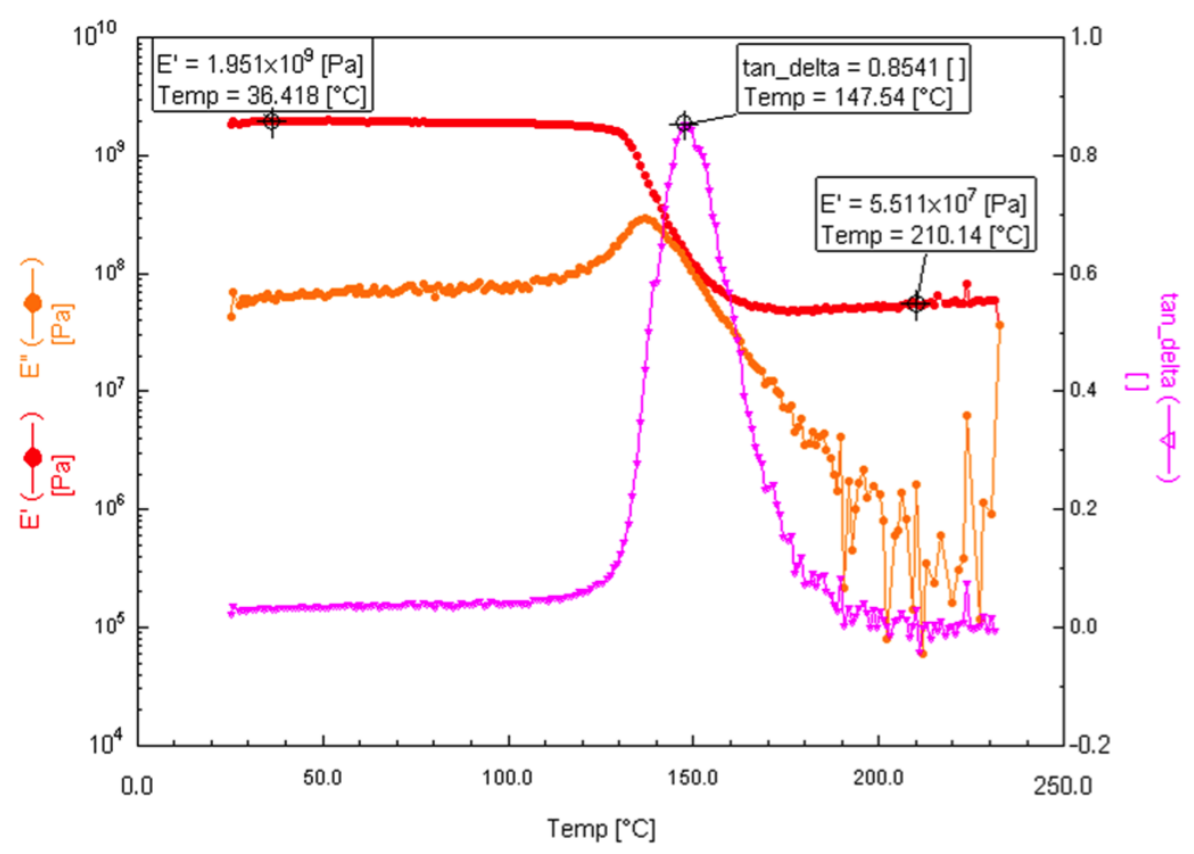

Figure 16. Storage modulus (E'), loss modulus (E') and tan delta from DMA of lignin-based epoxy resin with $20 \mathrm{wt} \%$ lignin with 3 point bending mode, with a frequency of $1 \mathrm{~Hz}$, an initial force of $0.5 \mathrm{~N}$ and a strain sweep of $0.01 \%$. 


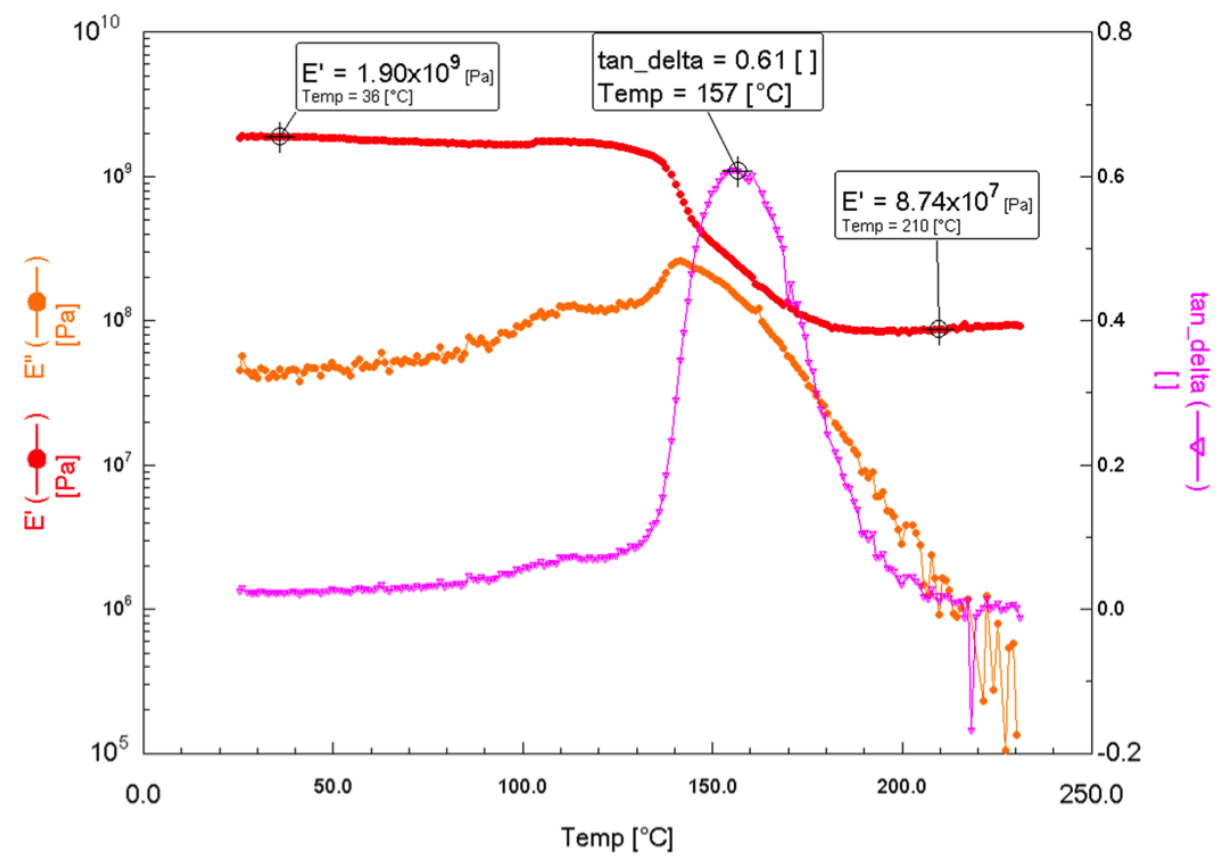

Figure 17. Storage modulus (E'), loss modulus (E') and tan delta from DMA of lignin-based epoxy resin with $28 \mathrm{wt} \%$ lignin with 3 point bending mode, with a frequency of $1 \mathrm{~Hz}$, an initial force of $0.5 \mathrm{~N}$ and a strain sweep of $0.01 \%$.

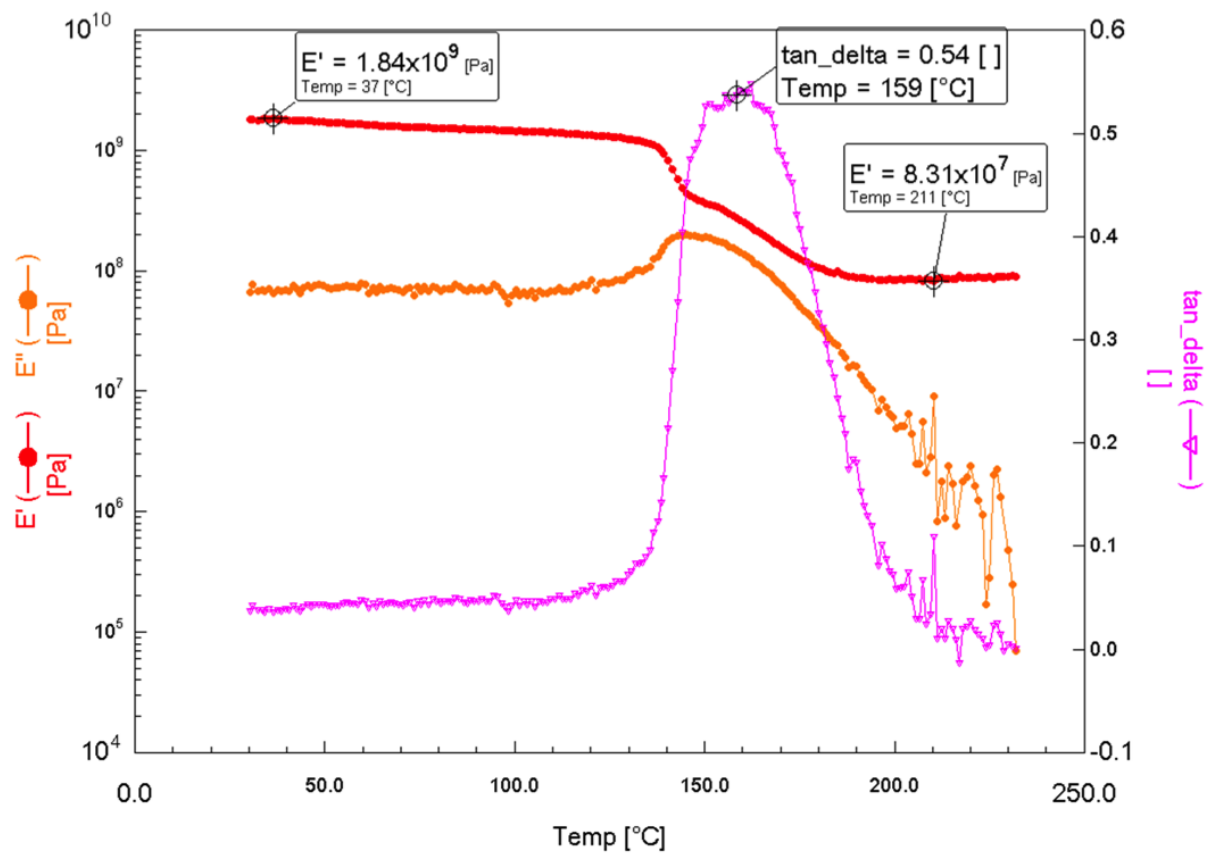

Figure 18. Storage modulus (E'), loss modulus (E') and tan delta from DMA of lignin-based epoxy resin with $33 \mathrm{wt} \%$ lignin with 3 point bending mode, with a frequency of $1 \mathrm{~Hz}$, an initial force of $0.5 \mathrm{~N}$ and a strain sweep of $0.01 \%$. 


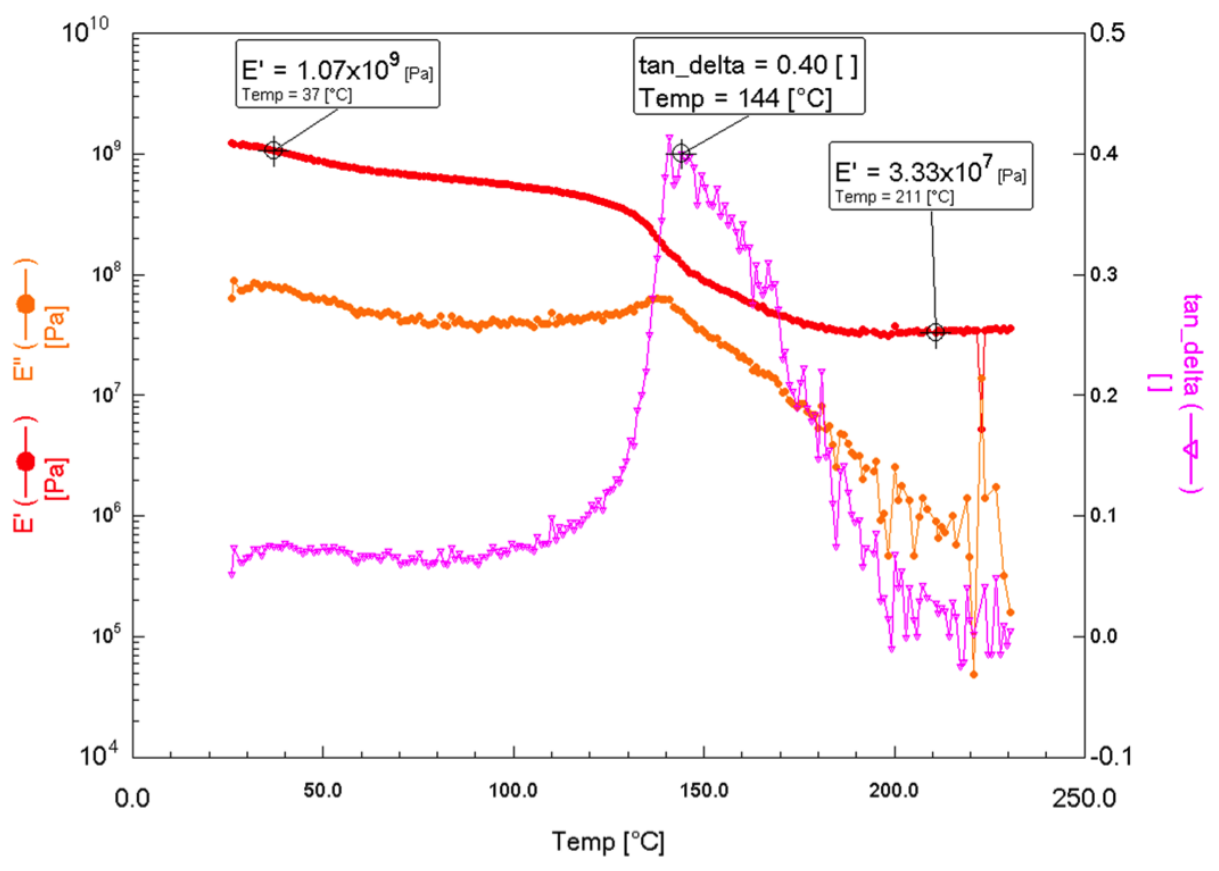

Figure 19. Storage modulus (E'), loss modulus (E') and tan delta from DMA of lignin-based epoxy resin with $42 \mathrm{wt} \%$ lignin with 3 point bending mode, with a frequency of $1 \mathrm{~Hz}$, an initial force of $0.5 \mathrm{~N}$ and a strain sweep of $0.01 \%$. 


\section{Stress/strain measurements}

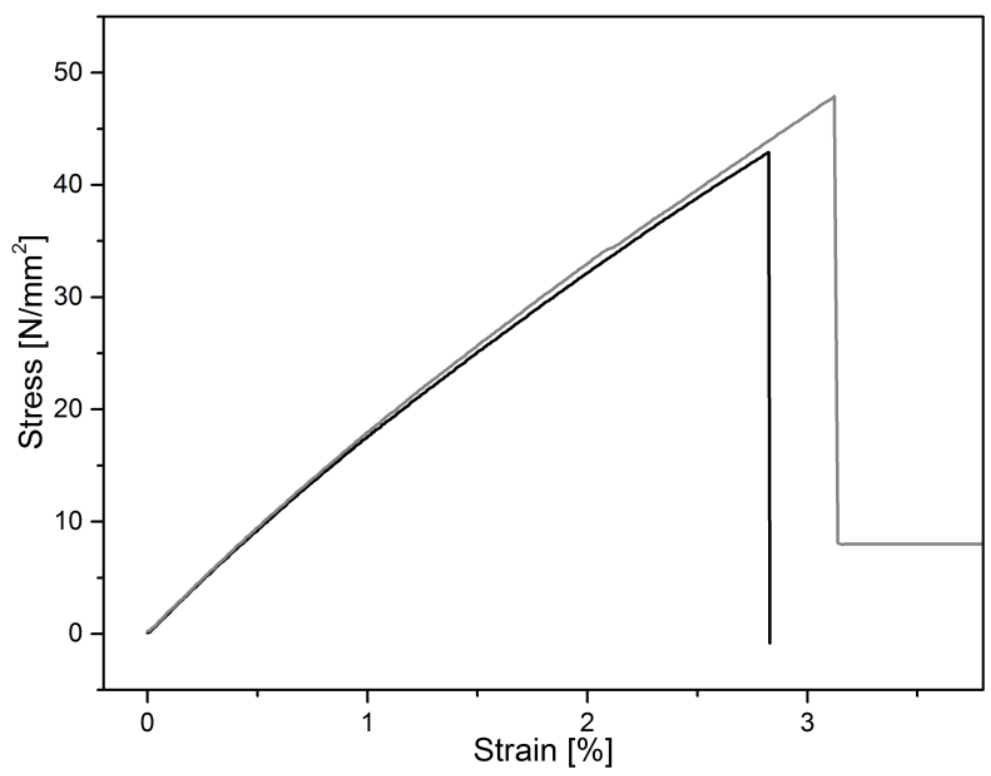

Figure 20. Stress/strain diagram for DGEBA-IPDA epoxy resin (0 wt\% lignin); Conditions: $500 \mathrm{~N}$ load cell and a crosshead speed of $1 \mathrm{~mm} \mathrm{~min}^{-1}$.

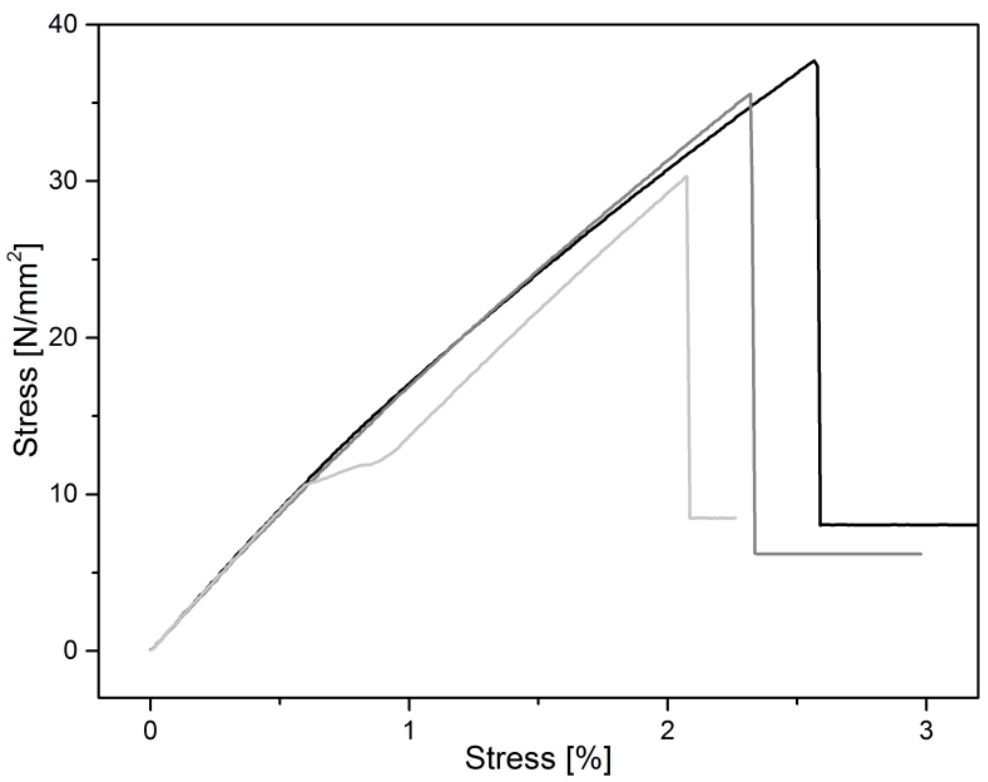

Figure 21. Stress/strain diagram for a epoxy resin with $8 \mathrm{wt} \%$ lignin. Conditions: $500 \mathrm{~N}$ load cell and a crosshead speed of $1 \mathrm{~mm} \mathrm{~min}^{-1}$. 


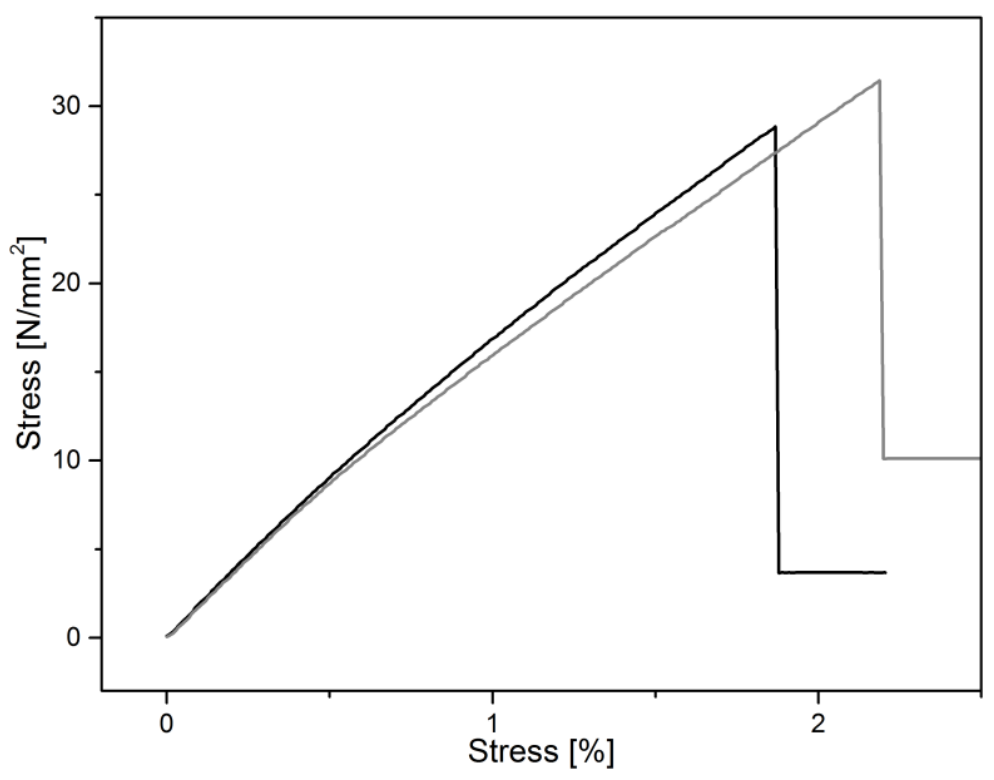

Figure 22. Stress/strain diagram for an epoxy resin with $20 \mathrm{wt} \%$ lignin; Conditions: $500 \mathrm{~N}$ load cell and a crosshead speed of $1 \mathrm{~mm} \mathrm{~min}^{-1}$.

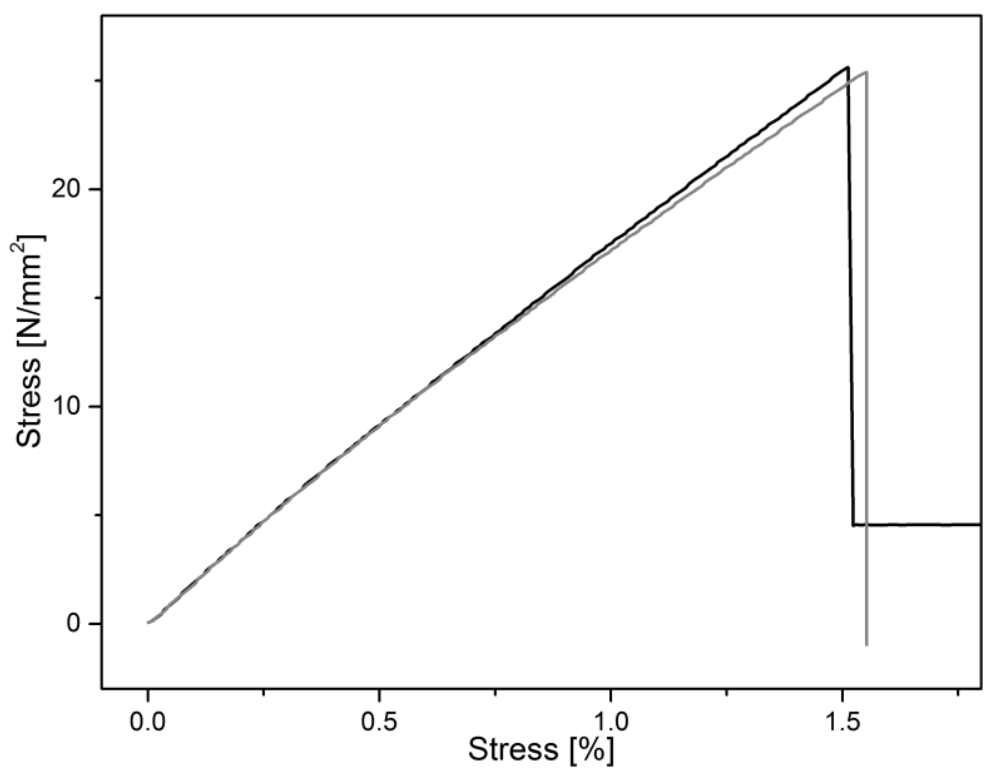

Figure 23. Stress/strain diagram for an epoxy resin with $28 \mathrm{wt} \%$ lignin. Conditions: $500 \mathrm{~N}$ load cell and a crosshead speed of $1 \mathrm{~mm} \mathrm{~min}^{-1}$. 


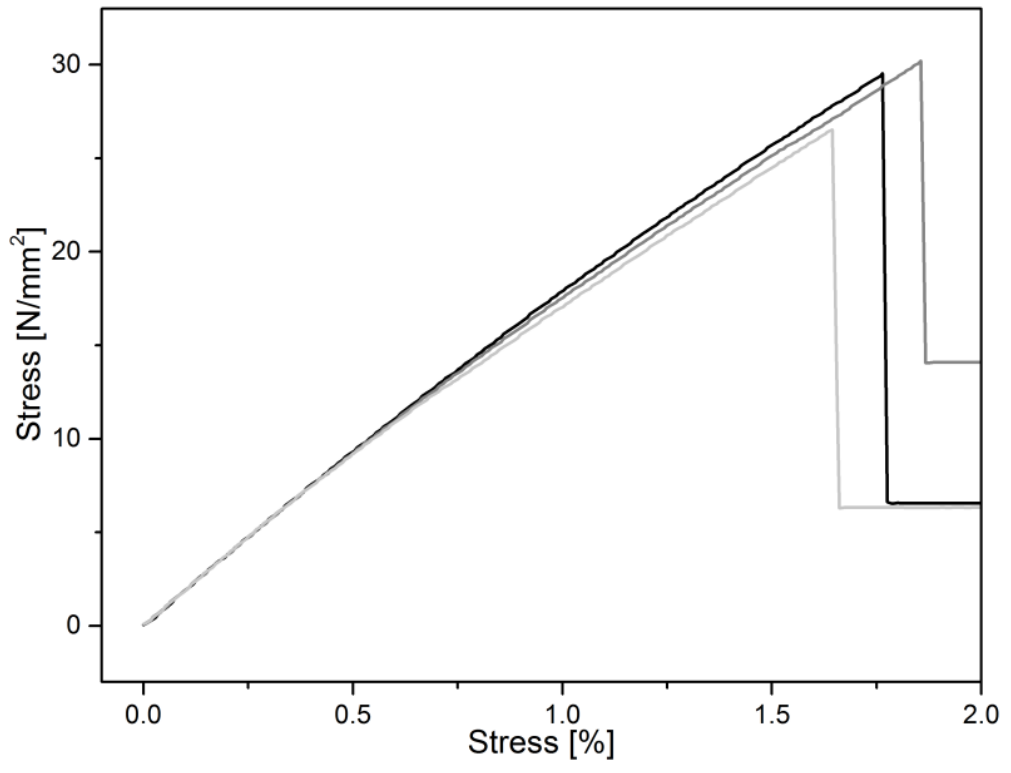

Figure 24. Stress/strain diagram for an epoxy resin with $33 \mathrm{wt} \%$ lignin. Conditions: $500 \mathrm{~N}$ load cell and a crosshead speed of $1 \mathrm{~mm} \mathrm{~min}^{-1}$. 